\title{
BACKSCATTERING SIGNATURES AT Ka, Ku, C AND S BANDS FROM LOW RESOLUTION RADAR ALTIMETRY OVER LAND
}

Frédéric Frappart ${ }^{1}$, Fabien Blarel ${ }^{1}$, Fabrice Papa $^{1}$, Catherine Prigent ${ }^{2}$, Eric Mougin ${ }^{3}$, Philippe Paillou $^{4}$, Frédéric Baup ${ }^{5}$, Pierre Zeiger ${ }^{1,3}$, Edward Salameh ${ }^{1,6}$, José Darrozes ${ }^{3}$, Luc Bourrel ${ }^{3}$, Frédérique Rémy ${ }^{1} \ldots$

${ }^{1}$ LEGOS, Université de Toulouse, CNES, CNRS, IRD, UPS -14 avenue Edouard Belin, 31400 Toulouse, France

2

${ }^{3}$ Géosciences Environnement Toulouse (GET), Observatoire Midi-Pyrénées, UMR 5563 (CNRS/UPS/IRD/CNES), 14 Avenue Edouard Belin, 31400 Toulouse, France 


\begin{abstract}
:
Radar backscattering coefficients from synthetic aperture radars and scatterometers are commonly used to characterize the land surface properties and monitor their temporal evolution. Radar altimetry is mostly used, over land, to provide time series of water stage of lakes, rivers and wetlands and the topography of the ice sheets. Very few studies used the radar altimetry backscattering coefficients for geophysical applications except to determine changes in Arctic lakes state surface, surface soil moisture in semi-arid environments or flood extent at high latitude. As radar altimetry missions acquired data in four frequency bands (mostly $\mathrm{C}$ and $\mathrm{Ku}$ but also $\mathrm{S}$ and $\mathrm{Ka}$ ), this study proposes the first thorough analysis of the backscattering signatures of land surfaces using observations from ERS-2, Jason-1, ENVISAT, Jason-2 and SARAL radar altimetry missions The spatial and temporal variations of several altimetric information (backscattering coefficient, waveform peakiness, leading edge width and trailing edge slope) are examined at global scale, for each frequency band separately, as well as for their differences. Their relationship with related variations in the surface characteristics are evidenced. Finally, spatial patterns and temporal variations computed over selected key regions are related to their surface properties and changes.
\end{abstract}




\section{Introduction}

Earth observation using active microwave sensors offers an all-weather global monitoring of the whole types of surface (ocean, land and ice-caps) in a wide range of frequencies, spatiotemporal resolutions, incidence angles and polarizations. Over land, backscattering coefficients $\left(\sigma_{0}\right)$ from radar scatterometers and Synthetic Aperture Radar (SAR) provide useful information on land surface characteristics related to land cover, vegetation density, surface soil moisture (SSM), salinity or detection of flooded areas, and the temporal dynamics of these key environmental variables. These observations are mostly aquired at $\mathrm{Ku}$ and $\mathrm{C}$ bands for scatterometers and L, X and C bands for SAR images. Baghdadi and Zribi (2016) and Frison et al., (2016) provides recent reviews on the use of radar data for characterizing land surface properties, and some examples of flood monitoring using SAR images at different frequency bands (e.g., Betbeder et al., 2014; Bourrel et al., 2009; Gstaiger et al., 2012; Kuenzer et al., 2013; Oberstadler et al., 1996).

Over land, radar altimetry (RA) data were mostly used for studying the changes in topography of the polar ice sheets and estimating water levels of inland water bodies (e.g., (Crétaux et al., 2017; Remy, 2016) for recent reviews on these topics). Nevertheless, some studies analyzed the spatial patterns of radar altimetry backscattering coefficients $\left(\sigma_{0}\right)$ over land and ice sheets and their temporal variations. RA backscattering coefficients from Topex/Poseidon and ENVISAT were related to the large-scale dynamics of surface properties over land and ice sheets (Legrésy et al., 2005; Papa et al., 2003). Over land, changes in RA $\sigma_{0}$ at C-band were used to detect flood extent and duration over boreal regions (Papa et al., 2006). Combined with the temporal variations of the brightness temperature onboard satellite altimetry missions, they allowed to monitor the changes in the state surface of the Arctic lakes from open water to ice cover (Kouraev et al., 2008, 2007, 2003). Signatures of soil roughness and changes in SSM over the semi-arid regions of West Africa and Australia were identified at $\mathrm{Ku}$ 
band using ERS-1 and Topex/Poseidon data respectively (Cudlip et al., 1993; Ridley et al., 1996). Spatio-temporal variations of the backscattering coefficient from Topex/Poseidon were also analyzed over China (Guo et al., 2013). Sensitivity of RA $\sigma_{0}$ to vegetation was also observed with the decrease of ENVISAT and Topex/Poseidon backscattering coefficients as vegetation increases in Sahel (Fatras et al., 2012; Prigent et al., 2015). In the latest and in (Fatras et al., 2015), a comprehensive comparison of radar signatures acquired over the major bioclimatic zones, soil and vegetation types encountered in West Africa (between $0^{\circ}$ and $25^{\circ} \mathrm{N}$ and $5^{\circ} \mathrm{W}-25^{\circ} \mathrm{E}$ ) was performed using $\sigma_{0}$ from RA and scatterometers acquired at both C- and Ku- bands. Among other, the study from (Fatras et al., 2015) shows RA backscattering coefficients were more correlated to SSM than the scatterometer ones that were found to be more correlated to the vegetation density. A similar study achieved a comparison of the RA backscattering signatures at the different frequency bands used up to now in satellite altimetry missions (i.e., S, C, Ku and Ka) over the same study sites of West Africa. It showed that the RA $\sigma_{0}$ decreased as the frequency increased from $\mathrm{S}$ to Ka bands under dry conditions whereas the amplitude of the variations is larger at higher frequencies in presence of changes in SSM or in wetlands between the dry and the wet seasons (Frappart et al., 2015a). Changes in $\sigma_{0}$ were found to be well correlated to SSM derived from the measurements of the Soil Moisture and Ocean Salinity (SMOS) mission at both $\mathrm{Ku}$ and $\mathrm{Ka}$ bands in Sahelian savannahs (Bonnefond et al., 2018). The effects of variations in SSM on the altimeter waveform through the changes in dielectrical properties of the soil at $\mathrm{Ku}$ and $\mathrm{Ka}$ bands were assessed using a semi-empirical modelling approach of the electromagnetic (EM) response of the surface in semi-arid areas (Fatras et al., 2018). First inversions of RA backscattering coefficients to retrieve SSM were performed using ENVISAT data over Sahelian savannahs in the Gourma region of Mali (Fatras et al., 2012) and using ENVISAT and Jason-2 over semi-arid regions of Australia (Uebbing et al., 2017). RA waveforms, backscattering coefficients, and other echo- 
derived parameters from several Low Resolution Mode (LRM) (ERS-2, ENVISAT and SARAL) and SAR (Cryosat-2) altimetry missions were used to discriminate between emerged and submerged areas in the intertidal zone of the Arcachon Bay, a lagoon along the French Atlantic coast, in the south of the bay of Biscay (Salameh et al., 2018). Nevertheless, until now, no study presented a thorough analysis of the land surface backscattering over land surfaces at global scale, in the different frequency bands used by the Low Resolution Mode (LRM) in orbit since the beginning of the high accuracy satellite era starting with the launch of ERS-1 in 1991 and Topex/Poseidon in 1992, in spite of their importance for the monitoring of the land surface properties.

In this study, we analysed the radar altimetry backscattering over land surfaces at $\mathrm{S}, \mathrm{C}, \mathrm{Ku}$ and $\mathrm{Ka}$ bands using data from ERS-2, Jason-1, ENVISAT, Jason-2 and SARAL on their nominal orbit. Firstly, we will briefly summarize the physical principle of radar altimetry backscattering and describe the retracking algorithms used to process the radar altimetry echoes over land. Then, we present the datasets used in this study and introduce the normalized pass structure developed to provide a homogenous grid information necessary to achieve statistical analysis along the tracks. Global maps of along-track average backscattering coefficients and associated standard deviation, seasonal amplitude, temporality of the maximum and minimum of backscattering at $\mathrm{S}, \mathrm{C}, \mathrm{Ku}$ and $\mathrm{Ka}$ over land are presented and analyzed. Similar maps of along-track averaged difference in backscattering coefficients between $\mathrm{C}$ and $\mathrm{Ku}$ (Jason-1 and Jason-2) and between $\mathrm{S}$ and $\mathrm{Ku}$ (ENVISAT) bands as well as complementary parameters from the retracking algorithms (peakiness, leading edge width and slope and trailing edge slope) and associated standard deviation are also analysed. Time-series of backscattering coefficients at $\mathrm{S}, \mathrm{C}, \mathrm{Ku}$ and $\mathrm{Ka}$ bands are presented over typical environments of different bio-climatic zones. These results are finally related to the nature of the land surface and its temporal evolution which affects its roughness and its dielectric 
properties.

\section{Radar altimetry backscattering}

This section gives a brief summary of the formation of the radar altimetry echo and a description of the most commonly used retracking algorithms for land surface studies.

\subsection{Radar altimetry echoes over land}

Over oceans, altimeter echoes can be represented as the sum of the reflections from elementary surface facets distributed around the mean surface. These elementary surfaces can be ordered by their arrival time that is used to derive the altimeter range defined as the twoway time-travel of the EM pulse emitted by the radar sensor (Brown, 1977). The radar echo (or waveform $W$ ) can be modeled as the convolution of the impulse response shape $(I)$ with the antenna pattern function $(A n t)$ and the point distribution function $(p d f)$ :

$$
W(t)=I \otimes p d f \otimes A n t
$$

Over land and ice sheets, the EM waves emitted by the altimeter can penetrate some of the underneath surfaces. The resulting radar response can be composed of surface and volume echoes. Over ice sheets, it is the sum of surface and snowpack layer echoes. Over land, the resulting waveform can be the sum of echoes from the canopy, ground layers and possibly snow layers depending on the wavelength of EM wave, the nature and the water content of the soil and the vegetation. For very smooth or very wet surfaces, the waveforms are almost specular. The echo shape is also affected by the surface topography slope and curvature. In these cases, it is necessary to take into account the scattering distribution $\left(f_{\text {scat }}\right)$ that describes the vertical profile of the reflecting surfaces to model the waveform (Legrésy et al., 2005):

$$
W(t)=I \otimes p d f \otimes f_{\text {scat }} \otimes A n t
$$


The detailed description of each parameter present in (2) and their physical significance can be found in (Legrésy et al., 2005) and (Frappart et al., 2016).

\subsection{OCOG retracking algorithm}

The Ice-1 (OCOG-Offset Centre of Gravity) retracking algorithm approach consists of approximating the radar altimetry waveform with a rectangle which has the same center of gravity as the waveform (Wingham et al., 1986). The rectangle is characterized by the three following parameters - centre of gravity (COG), amplitude (A), and width (W):

$$
\begin{aligned}
& \mathrm{COG}=\frac{\sum_{\mathrm{n}=1+\operatorname{aln}}^{\mathrm{n}=\mathrm{N}-\mathrm{aln}} \mathrm{ny}^{2}(\mathrm{n})}{\sum_{\mathrm{n}=1+\mathrm{Naln}}^{\mathrm{n}=\mathrm{N}-\mathrm{aln}} \mathrm{y}^{2}(\mathrm{n})} \\
& \mathrm{A}=\sqrt{\frac{\sum_{\mathrm{n}=1+\operatorname{aln}}^{\mathrm{n}=\mathrm{N}-\mathrm{aln}} \mathrm{y}^{4}(\mathrm{n})}{\sum_{\mathrm{n}=1+\operatorname{aln}}^{\mathrm{n}=\mathrm{N}-\mathrm{aln}} \mathrm{y}^{2}(\mathrm{n})}} \\
& \mathrm{W}=\frac{\left(\sum_{\mathrm{n}=1+\operatorname{aln}}^{\mathrm{n}=\mathrm{N}-\mathrm{aln}} \mathrm{y}^{2}(\mathrm{n})\right)^{2}}{\sum_{\mathrm{n}=1+\mathrm{Naln}}^{\mathrm{n}=\mathrm{aln}} \mathrm{y}^{4}(\mathrm{n})}
\end{aligned}
$$

where $\mathrm{N}$ is the total gate number, aln is the number of gates in the beginning and the ending of the waveform which are not considered, and $y(n)$ is the power of the $n^{\text {th }}$ gate.

The leading edge point (LEP) is given by:

$$
\mathrm{LEP}=\mathrm{COG}-0.5 \times \mathrm{W}
$$

The backscattering coefficient $\left(\sigma_{0}\right)$ and pulse peakiness (PP - (Laxon and Rapley, 1987)) are derived from the Ice-1 parameters as follows:

$$
\sigma_{0}^{\text {Ice-1 }}=10 \log _{10}(A)+K_{c a l}
$$

where $\mathrm{K}_{\mathrm{cal}}$ is the power scaling factor obtained taking into account the Automatic Gain Calibration (AGC), the antenna gain and a correction for Earth curvature (ESA, 2007).

The peakiness $(P P)$, which provides information on the waveform shape, is computed as the ratio of the maximum power (highest bin value) to the accumulated echo power above the retracking point (Peacock and Laxon, 2004). It is computed as follows: 


$$
\mathrm{PP}=\frac{\mathrm{P}_{\mathrm{max}} \times \mathrm{N}_{\text {right }}}{\sum_{\mathrm{i}=1}^{\mathrm{N}_{\mathrm{WF}}} \mathrm{P}_{\mathrm{i}}}
$$

where $N_{W F}$ is the total number of the waveform gates, and $N_{\text {right }}$ is a number of points to the right from the tracking point (i.e., above the retracking point).

\subsection{Ice-2 retracking algorithm}

Altimeter waveforms represent the variations against time of the energy backscattered by the surface and reaching the sensor. They are generally described as the succession of a leading edge and a trailing slope. Through (2), the leading edge width appears as an integration of the surface macro-roughness and small scale topographic features and is enlarged by the penetration effects. The trailing edge slope is related to mispointing of the antenna and can be enhanced by the volume effect, whose signal is delayed in time (Legrésy et al., 2005).

The Ice-2 retracking algorithm consists in fitting a theoretical model composed of an error function representing the leading edge and an exponential decrease for the trailing edge (Legrésy and Rémy, 1997) to the altimetry waveforms that are available in the L1 product or Sensor Data Records (SDRs). It provides the following outputs: i) the leading edge amplitude (LeBs), ii) the location of the epoch at mid-amplitude that is used to correct the range from instrument mistracking, iii) the leading edge width (LEW), iv) the trailing edge slope (TES), and v) the backscattering coefficient $\left(\sigma_{0}\right)$.

\section{Altimetry datasets}

The altimetry data used in this study are the following high frequency parameters available at 18,20 or $40 \mathrm{~Hz}$ depending on the mission: time, longitude, latitude, $\sigma_{0}$ and peakiness from the OCOG/Ice/Ice-1 retracking algorithm for all the missions considered in this study, $\sigma_{0}$, LEW and TES from the Ice-2 retracking algorithm for ERS-2, ENVISAT and SARAL. They are made available by Centre de Topographie des Océans et de l'Hydrosphère (CTOH - 
htttp://ctoh.legos.obs-mip.fr) a French observation service based at Laboratoire d'Etudes des Océans et de l'Hydrosphère (LEGOS - http://legos.obs-mip.fr). The major characteristics of the altimetry missions whose data are used in this study are summarized in Table 1.

Table 1. Main characteristics of the high precision radar altimetry missions used in this study.

\begin{tabular}{llll}
\hline Mission & Jason-1(1)/2(2) & ERS-2(3)/ENVISAT(4) & SARAL(5) \\
\hline Instrument & Poseidon-2/Poseidon-3 & RA/RA-2 & AltiKa \\
Space agency & CNES, NASA & ESA & CNES, \\
& & & ISRO \\
Operation & 2001-2013/2008-2016* & $1995-2003 / 2002-2010^{*+}$ & $2013-2016^{*}$ \\
Acquistion mode & LRM & LRM & LRM \\
Acquistion & Along-track & Along-track & Along-track \\
Frequency $(\mathrm{GHz})$ & $13.575(\mathrm{Ku})-5.3(\mathrm{C})$ & $13.8(\mathrm{Ku}) / 13.575(\mathrm{Ku})-3.2$ & $35.75(\mathrm{Ka})$ \\
& & $(\mathrm{S})$ & \\
Wavelength $(\mathrm{cm})$ & $2.21(\mathrm{Ku})-5.66(\mathrm{C})$ & $2.17(\mathrm{Ku}) / 2.21(\mathrm{Ku})-9.375$ & $0.84(\mathrm{Ka})$ \\
& & $(\mathrm{S})$ & \\
Pulse Repetition & $1800(\mathrm{Ku})$ & $1020(\mathrm{Ku})$ & 4000 \\
Frequency $(\mathrm{Hz})$ & $300(\mathrm{C})$ & $1795.33(\mathrm{Ku})$ & \\
& $2060^{* *}$ & $448.83(\mathrm{~S})$ & 500 \\
Chirp bandwidth $(\mathrm{MHz})$ & 320 & $330 / 80.5(\mathrm{Ku}$ ERS-2) & \\
& & $320 / 80 / 20(\mathrm{Ku}$ ENVISAT) & \\
Altitude $(\mathrm{km})$ & 1315 & $160(\mathrm{~S} \mathrm{ENVISAT})$ & 800 \\
Orbit inclination $\left({ }^{\circ}\right)$ & 66 & 800 & 98.55 \\
Repetitivity (days) & 9.9156 & 98.55 & 35 \\
Equatorial cross-track & 315 & 35 & 75 \\
separation $(\mathrm{km})$ & & 75 & \\
\hline
\end{tabular}

(1) (Carayon et al., 2003)

(2) (Desjonquères et al., 2010)

(3) (Levrini et al., 1984)

(4) (Benveniste et al., 2001)

(5) (Steunou et al., 2015)

* on the nominal orbit

** interlaced: $3 \mathrm{Ku}-1 \mathrm{C}-3 \mathrm{Ku}$

+ S-band data are flagged after January 2008 


\section{Methods}

\subsection{Normalized pass structure}

Normalized pass structure (Blarel et al., 2015) was defined to sort the altimetry data acquired by one or several missions on the same orbit (e.g., Topex/Poseidon, Jason-1, Jason-2 and Jason-3 or ERS-1\&2, ENVISAT and SARAL on their nominal orbits) into cell structure along a pass chosen arbitrarily as reference for all the cycles. This reference pass could be either the nominal pass provided by the space agencies before the launch of the mission, an average pass computed with the locations of the satellite during a specific period, or based on the locations of the satellite during a single cycle. The method to compute the structure of the normalized pass is based on the following assumption: the velocity of the satellite $\left(V_{\text {sat }}\right)$ is constant against time and it is then possible to index the data into the cells using a normalized time given by the lapsed time from the beginning of the pass.

The normalized pass structure is characterized by three parameters: the cell index and the cell size given by its dimensions along $\left(\delta_{\text {Along-track }}\right)$ and cross track $\left(\delta_{\text {Cross-track }}\right) . \delta_{\text {Cross-track }}$ is chosen arbitrarily. It equals to two kilometers in this study as this distance corresponds to the maximum cross-track variations along the orbit of the different altimetry missions. $\delta_{\text {Along-track }}$ is given by (Blarel et al., 2015) as:

$$
\delta_{\text {Along-track }}=V_{\text {sat }}{ }_{\text {ref }} \text { with }{ }_{\text {ref }} \geq T_{S} \geq \frac{1}{P R F}
$$

where $V_{\text {sat }}$ is the velocity of the satellite along the orbit equals to $7.45 \mathrm{~km} . \mathrm{s}^{-1}$ for ERS-1\&2 and ENVISAT, to $7.47 \mathrm{~km} . \mathrm{s}^{-1}$ for SARAL and to $5.8 \mathrm{~km} . \mathrm{s}^{-1}$ for Jason- 1 and 2 and $\Delta t_{\text {ref }}$ is the time definition of the cell, $T_{S}$ is the time sampling of the data along the track (e.g., typically a frequency $F_{s}\left(1 / T_{s}\right) 1 \mathrm{~Hz}$ in low frequency mode for all the missions, $10 \mathrm{~Hz}$ for T/P, $18 \mathrm{~Hz}$ for ENVISAT, $20 \mathrm{~Hz}$ for ERS-2 and Jason-2, and $40 \mathrm{~Hz}$ for SARAL in high-frequency mode), 
$P R F$ is the pulse repetition frequency of the mission.

In the followings, let us consider, first, the case of an ascending half-pass during the $\mathrm{k}^{\text {th }}$ cycle of any altimetry mission as presented in Fig. 1. The number of cells of an ascending half-track $N_{c e l l}^{r e f}$ is defined by (Blarel et al., 2015) as:

$$
N_{\text {cell }}^{r e f}=\frac{T_{e q}(k)-T_{m e r}(k)}{\Delta t_{r e f}}
$$

where $T_{e q}$ and $T_{m e r}$ are the times of equator and maximum latitude crossings. The number of cells is the same for any cycle as the satellite velocity is constant.

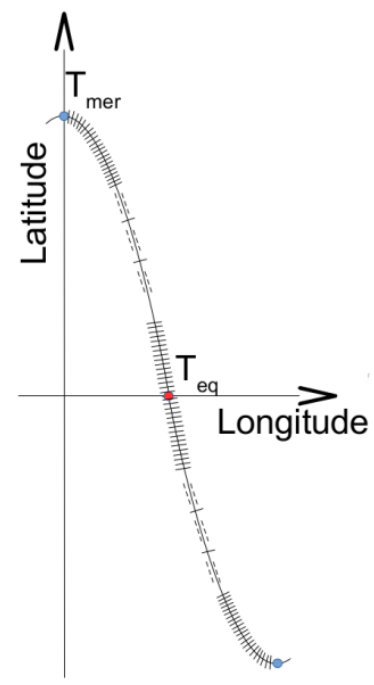

Figure 1: Example of cells along an altimetry track. The normalization method consists in defining cells along the altimetry tracks to allocate the data records.

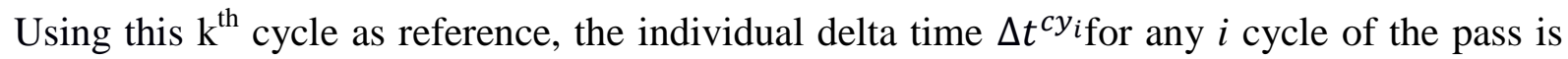
given by:

$$
\Delta t^{c y_{i}}=\frac{\left(T_{m e r i d}^{c y_{i}}-T_{e q}^{c y_{i}}\right)}{N_{\text {cell }}^{r e f}}
$$

where $T_{m e r i d}^{c y_{i}}$ and $T_{e q}^{c y_{i}}$ are respectively the time at the maximum latitude crossings and the time at the equator for the cycle $i$.

The normalized index of any measurement along of the pass at the time $T^{c y_{i}}$ for the cycle $i$ is 
obtained as:

$$
\operatorname{index}_{c e l l}\left(T^{c y_{i}}\right)=\operatorname{int}\left(\frac{\left(T^{c y_{i}-T_{e q}^{c y_{i}}}\right)}{\Delta t^{c y_{i}}}\right)
$$

This index is the cell number in the case of an ascending half-pass which forms the normalized pass structure.

This result can be generalized to the full ascending pass:

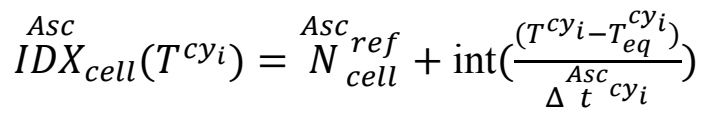

and the full descending pass:

$$
\stackrel{D s c}{I D X_{c e l l}}\left(T^{c y_{i}}\right)=\stackrel{D s c}{N}_{\text {cell }}^{r e f}+\operatorname{int}\left(\frac{\left(T_{e q}^{c y_{i}}-T^{c y_{i}}\right)}{\Delta_{t}^{D s c} c y_{i}}\right)
$$

Using the normalized pass structure, the averaged position $\left(\lambda_{\text {cell }}\right.$ and $\left.\varphi_{\text {cell }}\right)$ of each cell along the pass was determined taking into account the data from every cycle available during the life of the mission on the same orbit(red arrow in Fig.2). It is called "mean pass" in the followings.

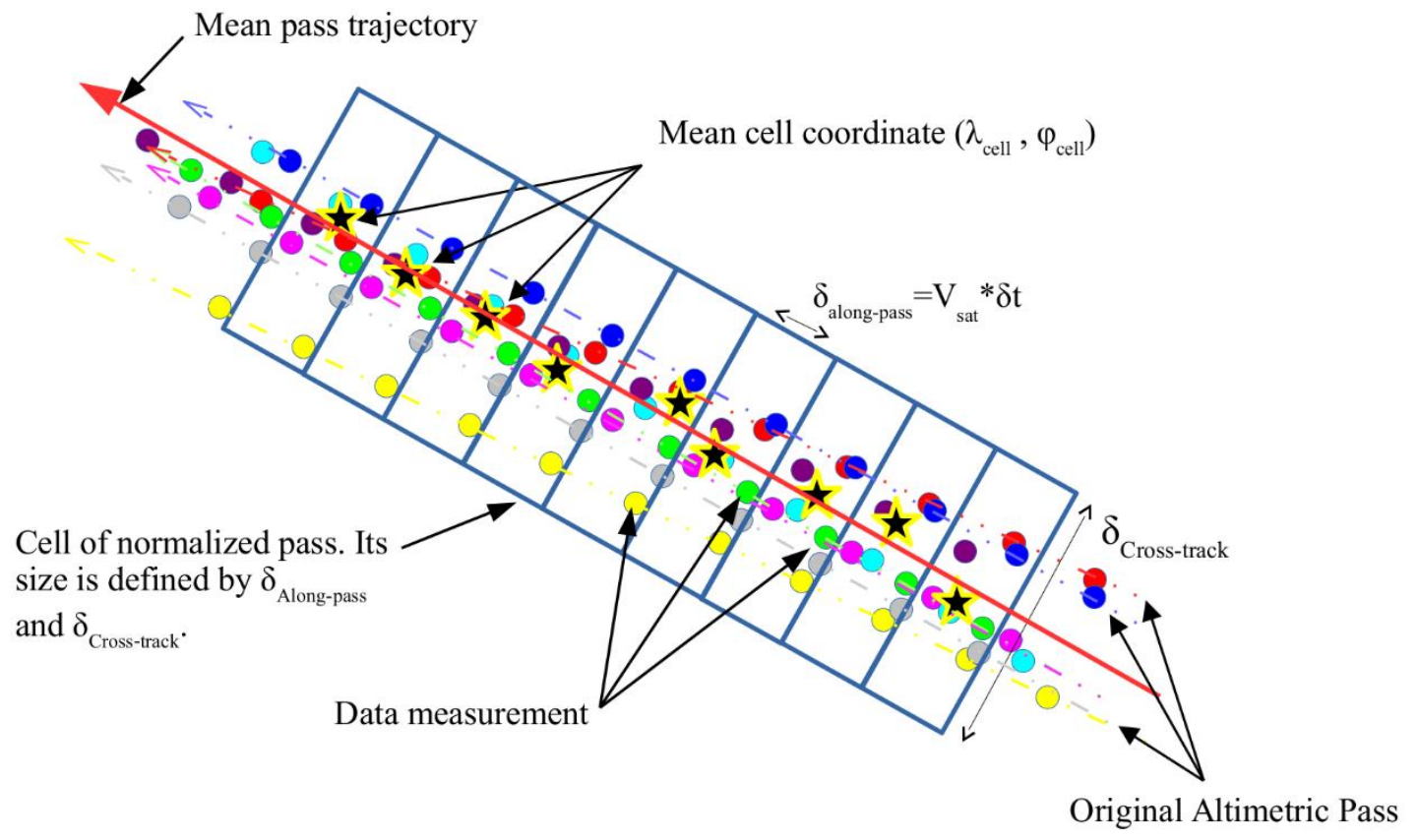

Figure 2: Average altimetry pass (black arrow) obtained as the average of all altimetry data 
acquired during the life time of an altimetry mission. Altimetry track for a given cycle (red arrow). Altimetry measurements are represented using dots, each color representing a cycle. Rectangles represent the cells along the altimetry track defined by $\delta_{\text {Along-track }}$ and $\delta_{\text {Cross-track }}$ for a given location $\left(\lambda_{\text {cell }}, \varphi_{\text {cell }}\right)$ (yellow and black star).

\subsection{Processing of the waveform related parameters along the track}

Several parameters were computed for each cell along the altimeter tracks of the different satellite missions considered in this study. For each cell, a four sigma filtering was applied over the whole observation period to eliminate the outliers (i.e., all values above or below the average plus or minus four times the standard deviation are filtered out) for all the parameters. The following indicators are considered for $\sigma_{0}$ at the different frequency bands and their differences ( $\mathrm{S}-\mathrm{Ku}$ and $\mathrm{C}-\mathrm{Ku})$ : mean, standard deviation, mean annual amplitude, month of occurrence of the extrema. Mean and standard deviation are also estimated for other parameters from the retracking algorithms which characterized the radar echo: the peakiness from Ice- 1 and LEW and TES from Ice-2.

In each cell, every cycle, the mean backscattering coefficient and the associated standard deviation were computed as follows:

$$
\left\langle\sigma_{0}\right\rangle_{d B}=10 \log _{10}\left(10^{\sigma_{0} / 10}\right)
$$

and

$$
\left.\operatorname{std}\left(\sigma_{0}\right)_{d B}=10 \log _{10}\left(1+\frac{s t d\left(10^{\sigma_{0} / 10}\right)}{\left\langle 10^{\sigma_{0} / 10}\right\rangle}\right)\right)
$$

where $\left\langle\sigma_{0}\right\rangle_{d B}$ and $\operatorname{std}\left(\sigma_{0}\right)_{d B}$ stand for the average of $\sigma_{0}$ in $\mathrm{dB}$ and its associated standard 
deviation in $\mathrm{dB}$, respectively. As the backscattering coefficients of the different altimetry missions are provided in $\mathrm{dB}$ in the GDRs, they were first converted into their natural values as expressed in (16) and (17).

Averaged backscattering coefficients and associated standard deviations were computed for the whole observation periods of ERS-2 at Ku-band (cycles 1-85 from May 1995 to July 2003), ENVISAT at Ku- (cycles 6-94 from June 2002 to October 2010) and S-bands (cycles 6-64 from June 2002 to January 2008 when RA-2 altimeter onboard ENVISAT stopped operating correctly at S-band), Jason-2 at Ku- and C-bands (cycles 1 to 259 from August 2008 to February 2016), and SARAL at Ka-band (cycles 1-25 from March 2013 to August 2015) using (10) and (11) over land.

\subsection{Time series of the backscattering coefficients}

Time series of backscattering coefficients estimated using the Ice-1 retracking algorithm are produced at crossings of tracks from the 10-day and the 35-day repeat orbits or close to these crossings on areas representative of an ecosystem or a land cover type. These time series are obtained by computing the median backscattering in a $0.1^{\circ}$ window size centered on the altimeter track crossing or on a close vicinity. Information on the crossings (location, type of surface, ...) are provided in Table 2. Data selection and processing were achieved using the

Multi-mission Altimetry Processing Software (MAPS) (Frappart et al., 2015b; Normandin et al., 2018a). No study site was considered over Africa as radar altimetry backscattering coefficients were already studied over the different eco-climatic zones of this continent (Fatras et al., 2015; Frappart et al., 2015a; Prigent et al., 2015). 
Table 2. Study sites types and locations. The altimeter track numbers are specified for both orbits. 10-day nominal orbit corresponds to Jason-1 (2002-2008) and 2 (2008-2016) missions, 35-day nominal orbit to ERS-2 (1995-2003), ENVISAT (2002-2010) and SARAL (20132016) missions.

\begin{tabular}{|c|c|c|c|c|c|}
\hline Orbit & $\begin{array}{c}\text { Altimeter } \\
\text { track number }\end{array}$ & $\begin{array}{l}\text { Averaged } \\
\text { latitude }\left(^{\circ}\right)\end{array}$ & $\begin{array}{c}\text { Averaged } \\
\text { longitude }\left({ }^{\circ}\right)\end{array}$ & $\begin{array}{c}\text { Study site } \\
\text { type }\end{array}$ & Country \\
\hline 10-day & 089 & -2.675 & -68.280 & Non-flooded forest & Brazil \\
\hline 35- day & 0121 & -2.502 & -68.300 & Non-flooded forest & Brazil \\
\hline 10-day & 165 & -2.578 & -65.410 & Flooded forest & Brazil \\
\hline 35- day & 0364 & -2.578 & -66.410 & Flooded forest & Brazil \\
\hline 10-day & 113 & -30.849 & -60.120 & Flooded savannah & Argentina \\
\hline 35- day & 035 & -30.849 & -60.120 & Flooded savannah & Argentina \\
\hline 10-day & 189 & -33.943 & -59.010 & River & Argentina \\
\hline 35- day & 0048 & -33.931 & -59.025 & River & Argentina \\
\hline 10-day & 029 & 37.880 & 79.880 & Desert & China \\
\hline 35- day & 0296 & 37.950 & 79.940 & Desert & China \\
\hline 10-day & 140 & 10.656 & 105.983 & Rice paddy & Vietnam \\
\hline 35-day & 322 & 10.656 & 105.983 & Rice paddy & Vietnam \\
\hline 10-day & 235 & 60.232 & 68.383 & Siberian lake & Russia \\
\hline 35-day & 0767 & 60.232 & 68.383 & Siberian lake & Russia \\
\hline 10-day & 166 & 60.680 & 55.093 & Siberian Taiga & Russia \\
\hline 35-day & 0900 & 60.680 & 55.093 & Siberian Taiga & Russia \\
\hline
\end{tabular}




\section{Results}

In the followings, only results obtained with Ice-1 retracking algorithm applied on all the missions will be presented. Results obtained using Ice- 2 retracking algorithm are presented in the supplementary material.

\subsection{Mean and Std backscattering}

Radar altimetry backscattering values averaged over the whole period of availability of the different altimetry missions considered in this study (ERS-2, Jason-1, ENVISAT, Jason-2 and SARAL) range between -10 and $35 \mathrm{~dB}$ at Ku-band (Figs. 3a, c, e and g with Ice-1 retracker and Figs. S1a, and c with Ice-2 for ENVISAT and ERS-2 respectively), between -5 and $40 \mathrm{~dB}$ at $\mathrm{S}$ and $\mathrm{C}$ bands (Figs. 3b, $\mathrm{f}$ and $\mathrm{h}$ with Ice-1 retracker and Figs. S1b with Ice-2 for ENVISAT), and between -5 and $35 \mathrm{~dB}$ at Ka-band (Fig. $2 \mathrm{~d}$ with Ice-1 and Fig. S1 d with Ice2 for SARAL). Spatial patterns of average backscattering are very consistent between the observations acquired by the different LRM missions in the different frequency bands $(\mathrm{S}, \mathrm{C}$, $\mathrm{Ku}$ and $\mathrm{Ka}$ ). They only differ in magnitude, larger values being observed at $\mathrm{S}, \mathrm{C}$ and also $\mathrm{Ka}$ bands than at $\mathrm{Ku}$ band.

In spite of a large increase in the number of available valid data in Jason-1 GDR-E data, a lower number is available for this mission compared to Jason-2. Over some region as northern Asia, almost no data are present in the GDR files causing the large gaps which can be seen on the different figures.

Altimetry backscattering is low $(<5 \mathrm{~dB}$ at Ku-band, $<7 \mathrm{~dB}$ at $\mathrm{S}$ and $\mathrm{C}$ bands, and $<2.5 \mathrm{~dB}$ at Ka-band) over mountainous regions (Himalaya, Andes, Rocky Mountains). Largest values, over $25 \mathrm{~dB}$ at $\mathrm{Ku}-$ and $\mathrm{Ka}$-bands and $30 \mathrm{~dB}$ at $\mathrm{S}$ and $\mathrm{C}$ bands, are found over flat areas such as 
deserts, peri-arctic areas and large river basins with extensive wetlands, as well as in large irrigated and deltaic zones. These regions can be very clearly identified at Ka band (Figs. 3d and S1 for Ice-1 and Ice-2 respectively). For example, this is visible in large regions of the Sahara, in Arabian, Gobi and Australian deserts, along the Ganges River basin, and especially in the Ganges-Brahmaputra-Meghna delta, the Plata or the Ob River', a large peri-arctic river with extensive seasonal floodplains. Along the Ganges and in the Mekong basins, the large backscattering values are also due to the inundated rice paddies. Similar patterns were found at $\mathrm{Ku}$ and $\mathrm{C}$ bands using Topex/Poseidon data processed using the Ocean retracker (Papa et al., 2003). Over rivers with extensive floodplains covered with forest, as in the Amazon Basin, the mean backscattering coefficient is low due to the presence of dense canopies once averaged on $7 \mathrm{~km}$ along the track, especially at low frequencies as $\mathrm{C}$ and $\mathrm{S}$ bands (Figs. 3b, $\mathrm{f}$ and $h$ with Ice-1 and Figs. S1b with Ice-2 for ENVISAT). At high latitudes, in peri-arctic basins, covered with snow from fall to spring, the backscattering increases with decreasing frequency (from Ka to $\mathrm{S}$ ) and increasing footprint is. Similar patterns are observed using Ice-2 retracker but with lower magnitude, except at Ka band.

The corresponding standard deviation of the radar altimetry backscattering coefficients varies from 0 to $4.5 \mathrm{~dB}$ at $\mathrm{Ku}$ band (Figs. $4 \mathrm{a}$, c, e and g with Ice-1 retracker and Figs. S2a, and c with Ice-2 for ENVISAT and ERS-2 respectively), 0.5 to $4.5 \mathrm{~dB}$ at $\mathrm{S}$ and $\mathrm{C}$ bands (Figs. $4 \mathrm{~b}, \mathrm{f}$ and h with Ice-1 retracker and Figs. S2b with Ice-2 for ENVISAT), and 1 to $5 \mathrm{~dB}$ at Ka-band (Fig. 4d with Ice-1 and Fig. S2 d with Ice-2 for SARAL). As for the mean backscattering coefficients, the patterns of std of backscattering are very consistent between the data acquired by the different LRM missions in the different frequency bands $(\mathrm{S}, \mathrm{C}, \mathrm{Ku}$ and $\mathrm{Ka}$ ). They only differ in magnitude. larger values are observed as the frequency increases from $S$ to Ka (except for ERS-2).

Lower deviation ( $<2 \mathrm{~dB}$ at $\mathrm{S}, \mathrm{C}$ and $\mathrm{Ku}$ bands and $<2.5 \mathrm{~dB}$ at Ka-band) are observed over arid 
and semi-arid areas. Mountainous areas also generally exhibit quite low deviation but higher than semi-arid areas. Their spatial pattern is not so clearly marked as it represents the average backscattering. Large values of deviation, between 4 and $5 \mathrm{~dB}$, can be seen in large tropical river basins at $\mathrm{S}, \mathrm{C}$ and $\mathrm{Ku}$ bands, and over the whole tropics at $\mathrm{Ka}$ band, except over deserts. Largest values of std (> $5 \mathrm{~dB}$ ) at observed at high latitudes over region covered with lakes as northern Canada, Sweden and Finland, and over the large river basins covered with extensive floodplains such as the McKenzie (Canada), Ob', Yenissey and Lena Basins (Siberia) (Fig. 4 with Ice-1 retracker and Fig. S2 with Ice-2). 

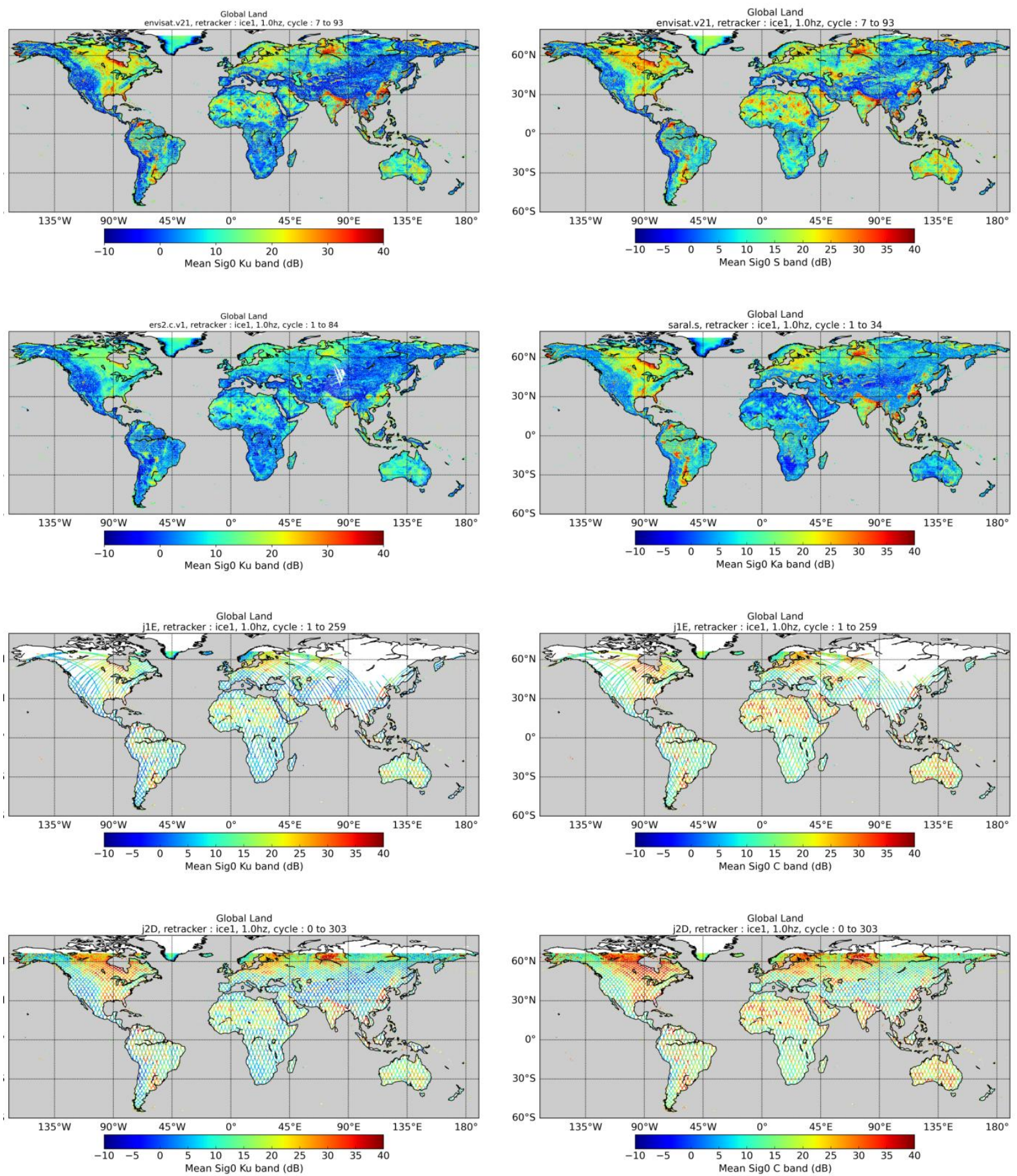

Figure 3: Maps of along-track averaged radar altimetry backscattering coefficients processed using Ice-1 retracker over land surfaces from ENVISAT at Ku and $\mathrm{S}$ band (a, b), ERS-2 at $\mathrm{Ku}$ band (c), SARAL at Ka band (d), Jason-1 and 2 at $\mathrm{Ku}$ and $\mathrm{C}$ bands (e, f) and (g, h), respectively during their nominal orbit period. 

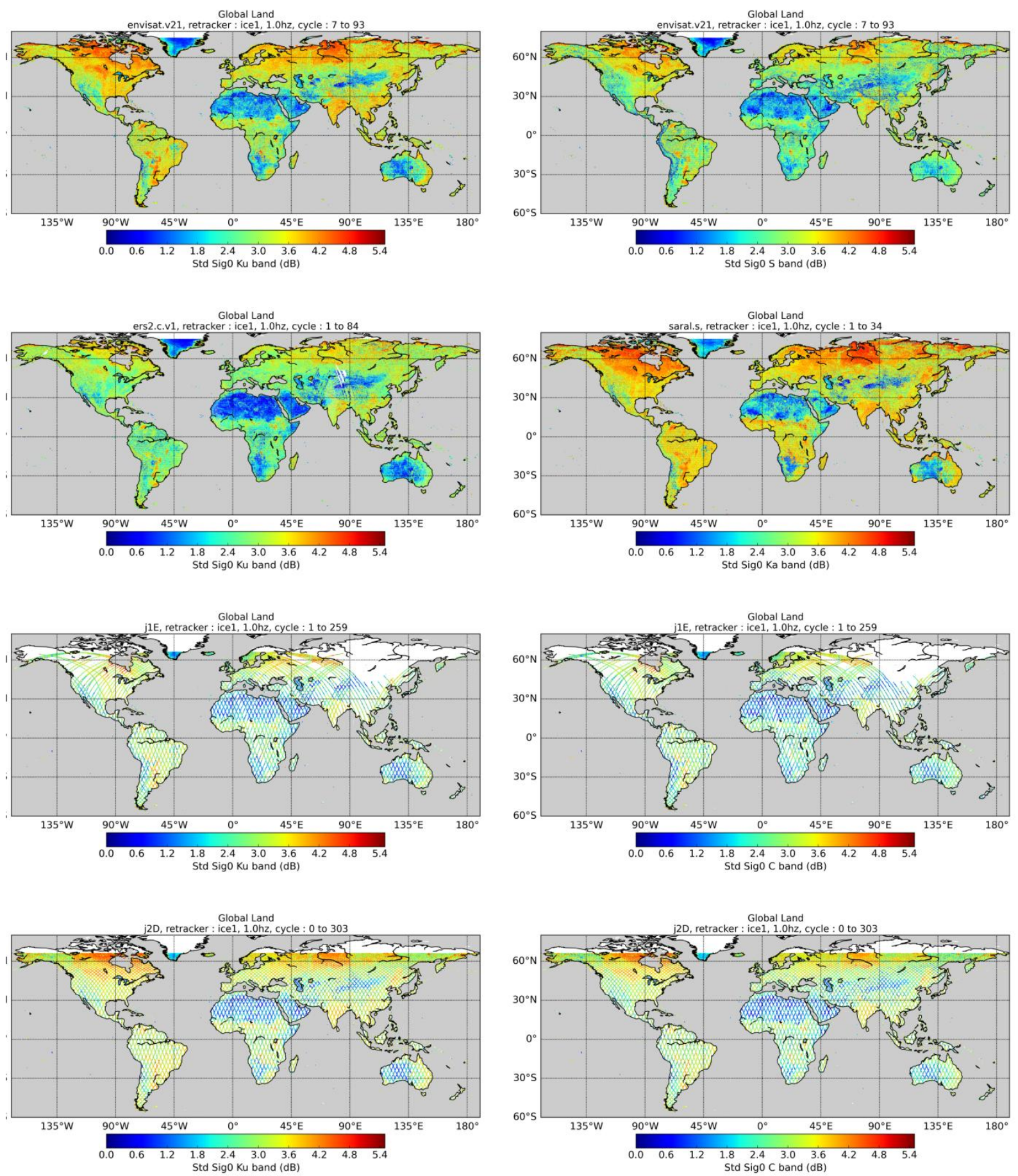

Figure 4: Maps of along-track standard deviation of radar altimetry backscattering coefficients processed using Ice-1 retracker over land surfaces from ENVISAT at Ku and S band (a, b), ERS-2 at Ku band (c), SARAL at Ka band (d), Jason-1 and 2 at $\mathrm{Ku}$ and $\mathrm{C}$ bands (e, f) and (g, h), respectively during their nominal orbit period. 


\subsection{Mean annual amplitude and seasonality of the backscattering}

Figs. 4 and S2 suggest that important variations of backscattering occurred during the observation period for the different altimetry missions. To better characterize them, mean annual amplitude of the backscattering obtained using Ice-1 and Ice-2 retrackers were estimated over land surfaces (Figs. 5 and S3). The mean annual amplitude ranges between 0 and $30 \mathrm{~dB}$ with Ice-1/Ice-2 retrackers respectively, at Ku and Ka bands (Figs. 5a, b, d, e, and g, and S3a, and d) and between 0 and $20 \mathrm{~dB}$ at $\mathrm{C}$ and $\mathrm{S}$ bands (Fig. 5b, f and h and S3b).

Low amplitudes are observed over mountainous areas, arid and semi-arid areas except Sahel, as well as in equatorial forests of the Amazon and Congo River basins or in Indonesia. The mean annual amplitudes are maximum over rivers and floodplains in large drainage basins for all the frequency bands. At high latitudes, lower amplitudes are observed in some regions as over the eastern part of Canada or the Ob' Basin, at low frequencies ( $\mathrm{S}$ and $\mathrm{C}$ ) but not at high frequencies ( $\mathrm{Ku}$ and $\mathrm{Ka}$ ). Secondary maxima can be observed over the African savannahs in Sahel and the south of Africa.

The seasonality of the minimum and maximum of backscattering is presented in Figs. 6 and 7 for all the altimetry missions considered in this study. For the seasonality of maximum of backscattering, very similar patterns are present for all the bands with some slight changes in phase (Fig. 6). They are generally clearer at lower frequencies (S, C and $\mathrm{Ku}$ ) than at $\mathrm{Ka}$ band. In the extra-tropical areas of the northern hemisphere, a latitudinal gradient can be observed with maximum values of backscattering reached from February in the south to AugustSeptember in the north. The opposite is observed in extra-tropical South America and also in Australia. Maximum of $\sigma_{0}$ is observed in August over Mexico, Sahel, and from India to the Mekong Basin, whereas they are observed in February in the savannahs in the south of Africa. In South America, maxima are reached in July in the Orinoco and in June in the northern part 
of the Amazon Basin, and from January to April in the part located in the southern hemisphere. Over arid areas such as the Sahara or the Arabic peninsula, no clear pattern is distinguishable (Fig. 6).

For the seasonality of the backscattering minimum, larger differences in patterns between the different bands can be observed (Fig. 7). As for the seasonality of the maximum of amplitude, much clearer patterns are observed at $\mathrm{S}$ and $\mathrm{C}$ bands than at $\mathrm{Ku}$ and above all at $\mathrm{Ka}$ bands. Minima occurred in August over the east coast of the USA, Europe (except the north of Scandinavia) and Himalaya for all the bands, from December to February in central US, Russia and extra-tropical China, and in March-April at northern latitudes. A north-south gradient is clearly visible over Australia with a different temporality for each frequency band. A much clearer shift of phase between the northern and the southern hemisphere, not only in tropical South America (minima from February to May in the north, from August to October in the south, except in a band along the Atlantic coast over the south of Brazil and parts of Uruguay and Argentina and over the Pacific side) but also in equatorial Africa (same temporality as for South America). Minima over arid areas exhibit a clear pattern at $\mathrm{S}$ band with minima observed in May/June over the Sahara, the Arabic peninsula and central Asia desert areas. Minima over Mexico and India occurred in April/May. 

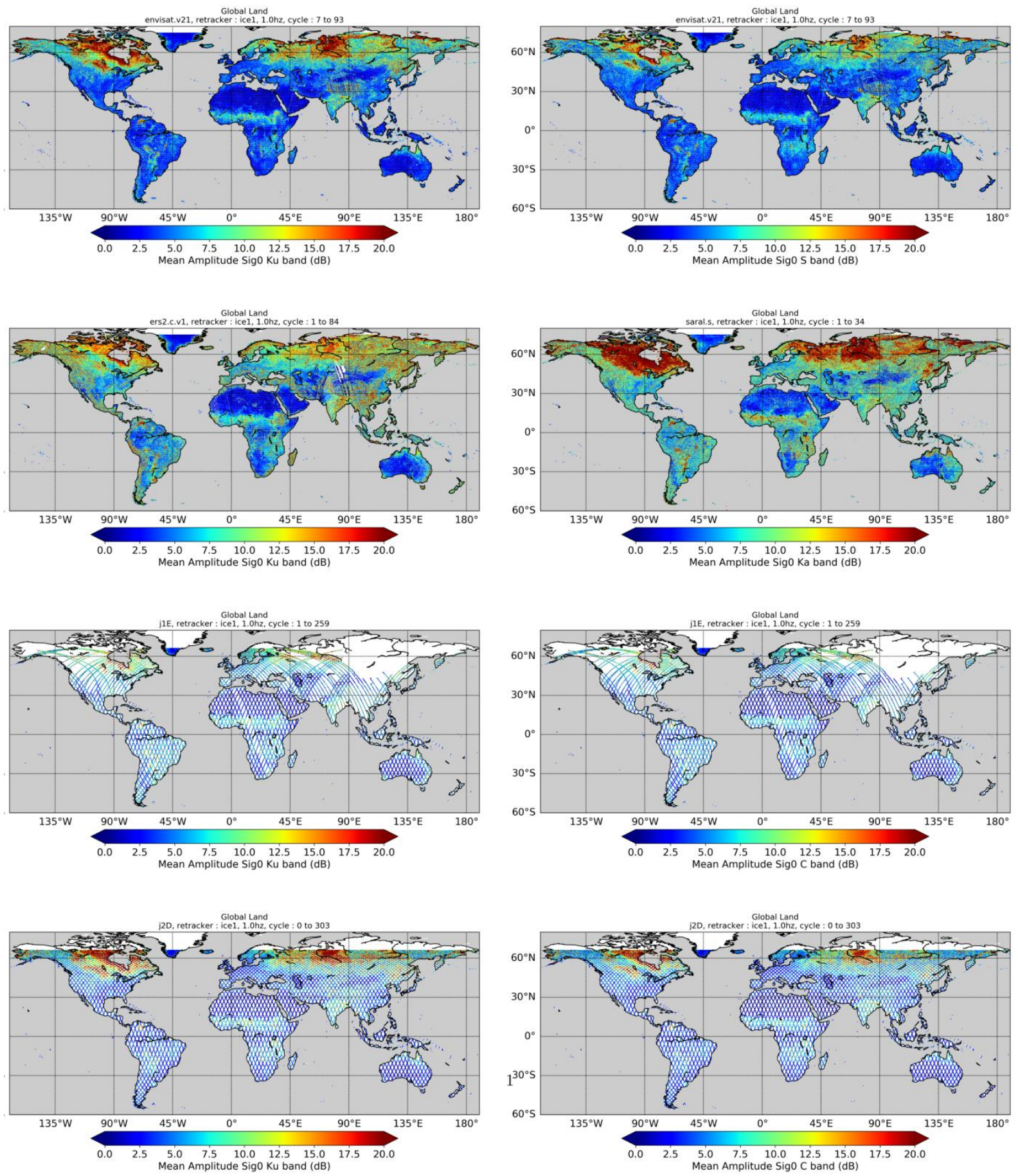

Figure 5: Maps of along-track annual amplitude of radar altimetry backscattering coefficients processed using Ice-1 retracker over land surfaces from ENVISAT at $\mathrm{Ku}$ and $\mathrm{S}$ band (a, b), ERS-2 at Ku band (c), SARAL at Ka band (d), Jason-1 and 2 at $\mathrm{Ku}$ and $\mathrm{C}$ bands (e, f) and (g, h), respectively during their nominal orbit period. 

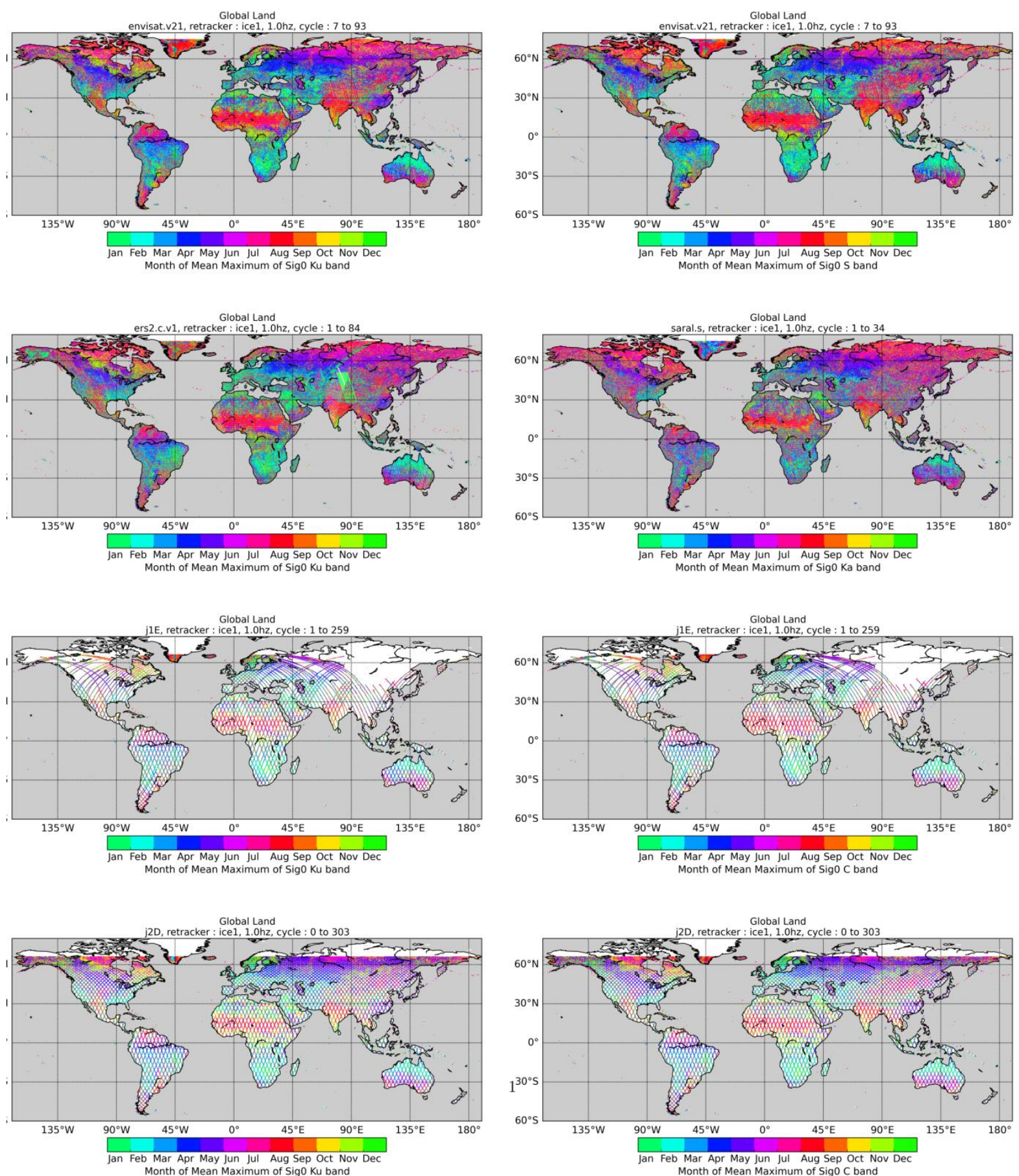

Figure 6: Maps of along-track month of maximum value of radar altimetry backscattering coefficients processed using Ice-1 retracker over land surfaces from ENVISAT at Ku and S band (a, b), ERS-2 at Ku band (c), SARAL at Ka band (d), Jason-1 and 2 at $\mathrm{Ku}$ and $\mathrm{C}$ bands $(e, f)$ and $(g, h)$, respectively during their nominal orbit period. 

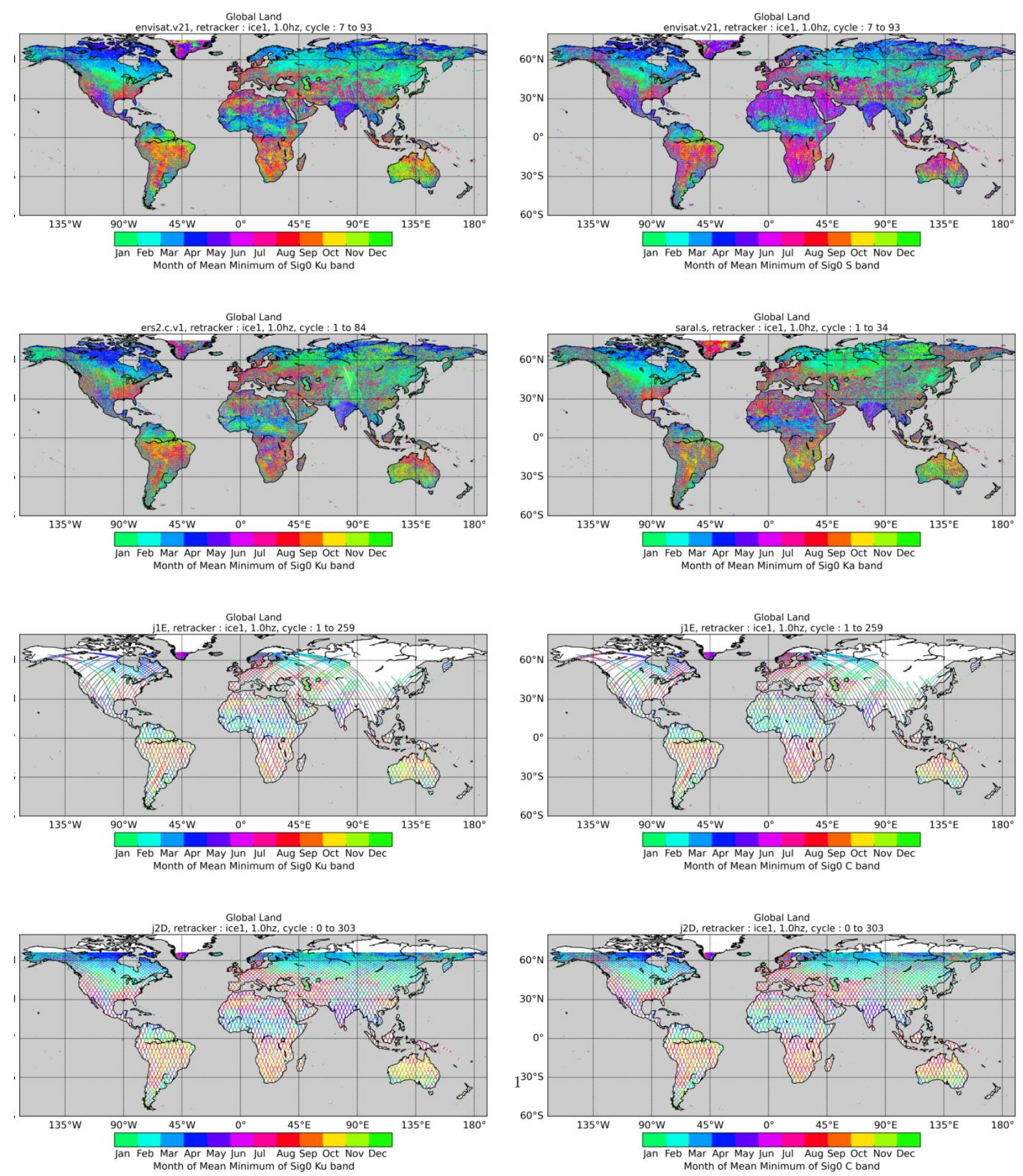

Figure 7: Maps of along-track month of minimum value of radar altimetry backscattering coefficients processed using Ice-1 retracker over land surfaces from ENVISAT at Ku and S band (a, b), ERS-2 at Ku band (c), SARAL at Ka band (d), Jason-1 and 2 at Ku and $\mathrm{C}$ bands $(\mathrm{e}, \mathrm{f})$ and $(\mathrm{g}, \mathrm{h})$, respectively during their nominal orbit period. 


\subsection{Differences in response between the bands}

The previous sub-sections clearly exhibit differences of magnitudes, amplitudes, and seasonality between the different frequency bands. Three altimeters acquired simultaneously data in two frequencies: Envisat at $\mathrm{Ku}$ and $\mathrm{S}$ bands, Jason-1 and Jason-2 at $\mathrm{Ku}$ and $\mathrm{C}$ bands. If the spatial patterns between the differences $\mathrm{S}-\mathrm{Ku}$ and $\mathrm{C}-\mathrm{Ku}$ are very similar, lower and more negative values are observed between $\mathrm{S}$ and $\mathrm{Ku}$ bands than $\mathrm{C}$ and $\mathrm{Ku}$ bands (Figs. 8 using the Ice-1 retracker). Less marked differences are also observed using Ice-2 rather than Ice-1 retracker (Fig. S4).

Low and negative values of difference in backscattering between frequency bands were observed over mountainous (Andes, Rocky Mountains, Himalaya, ...) and forested areas (Amazonia, Congo, Siberian forests). On the other hand, differences ranging from 15 to $35 \mathrm{~dB}$ with Envisat (S-Ku) and from 15 to $40 \mathrm{~dB}$ with Jason-1 are observed over arid and semi-arid areas, large rivers (Mississippi, Amazon, La Plata, Orinoco, Sao Francisco, Congo, GangesBrahmaputra), extended floodplains (Pantanal, Inner Niger Delta), large lakes (Baikal, Tonle Sap) or regions covered with small lakes as the northern Canada. Over very large lakes as the American Great Lakes or the Caspian Sea, the differences are lower, around $10 \mathrm{~dB}$ (Fig. 8).

The standard deviations of the differences exhibit similar patterns as the ones from the backscattering coefficients but with larger values reaching $10 \mathrm{~dB}$ over the large rivers and the northern Canada for S-Ku (Figs. 9 and S5). 

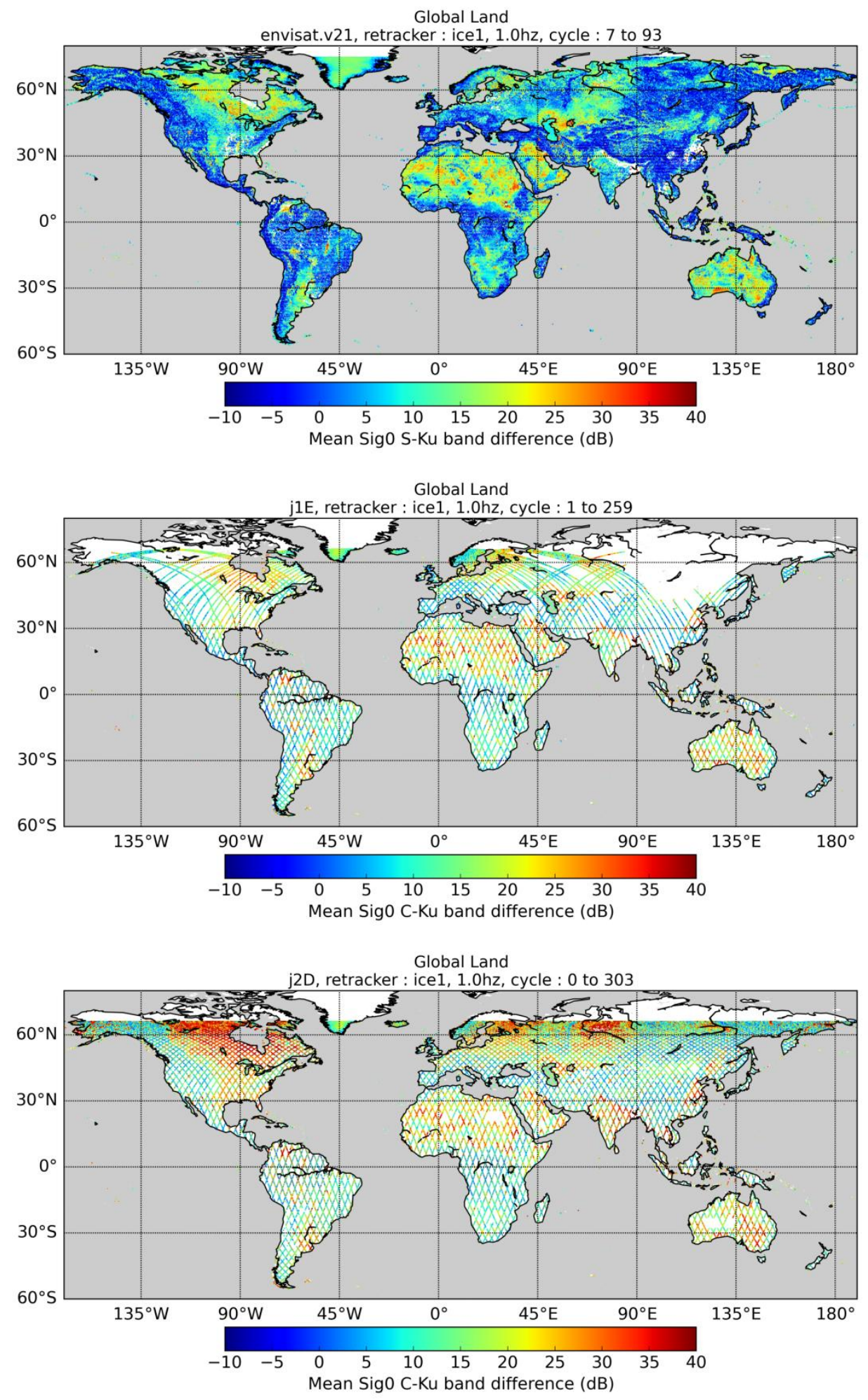

Figure 8: Maps of along-track average of radar altimetry backscattering coefficients difference between both bands $-\mathrm{S}$ and $\mathrm{Ku}$ for Envisat (a), $\mathrm{C}$ and $\mathrm{Ku}$ for Jason-1 and 2 (b) and c) respectively), processed using Ice-1 retracker over land surfaces from ENVISAT during its nominal orbit period. 

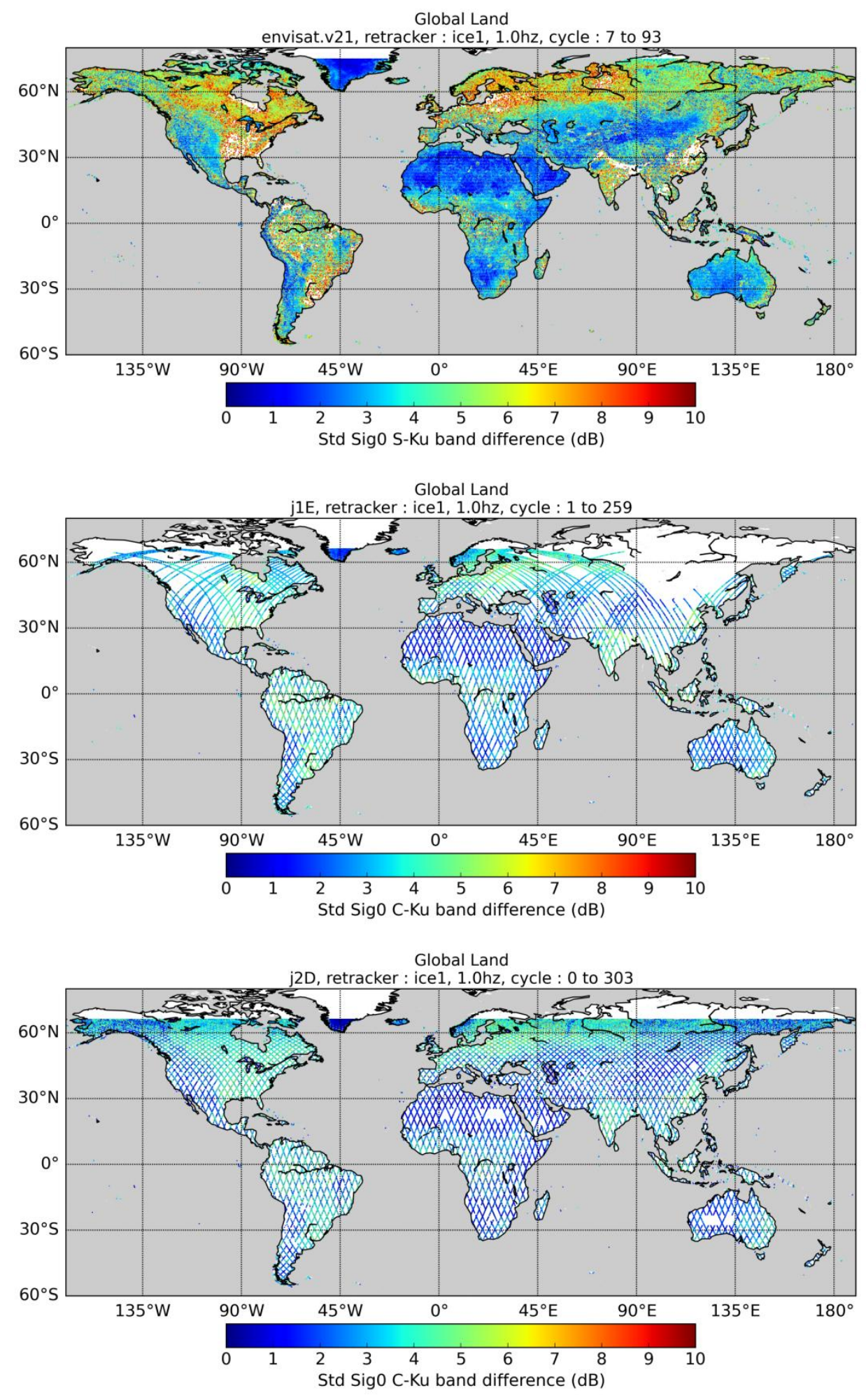

Figure 9: Maps of along-track standard deviation of radar altimetry backscattering coefficients difference between both bands $-\mathrm{S}$ and $\mathrm{Ku}$ for Envisat (a), $\mathrm{C}$ and $\mathrm{Ku}$ for Jason-1 and 2 (b) and c) respectively), processed using Ice-1 retracker over land surfaces from ENVISAT during its nominal orbit period. 


\subsection{Other parameters characterizing the waveform}

Besides the backscattering coefficient, which is related to the amplitude of the radar echo received on-board the altimeter, Ice-1 and Ice- 2 retracking algorithms also provide other parameters related to the shape of the echo, such as the peakiness for Ice-1 and LEW and TES for Ice-2.

Mean peakiness provides very similar spatial patterns for all bands but it increases with the frequency from $\mathrm{S}$ to $\mathrm{Ka}$ (Fig. 10). Mountains and forests exhibit low peakiness, below 2 at $\mathrm{S}$ and $\mathrm{C}$ bands and 6 at $\mathrm{Ku}$ and $\mathrm{Ka}$ bands. But contrary to the backscattering coefficients, it provides much clearer patterns over other surface types. Over arid areas, the peakiness is also low and homogeneous, especially at $\mathrm{S}$ and $\mathrm{C}$ bands (Figs. 10b, $\mathrm{f}$ and $\mathrm{h}$ ). As the frequency increases, the peakiness increases and some small heterogeneities are visible at $\mathrm{Ku}$ and $\mathrm{Ka}$ bands (Figs. 10a, c, d, e and g). High peakiness values, ranging between 12 and 20 depending on the frequency band, are observed over all types of inland water bodies: lakes, reservoirs, floodplains, wetlands, and rivers. The river networks and floodplain extents are very well delineated with the peakiness, especially at Ka band (Fig. 10d). Mean LEW and TES from Ice-2 exhibits low values over rivers, lakes and floodplains such as the Amazon, La Plata, Ganges, Ob' basins and Canadians lakes as well as over flat sandy areas as parts of Sahara, Arabian Peninsula, or Australia. Larger values are observed over mountains (Himalaya, Rocky mountains), sand dunes, and vegetated areas (Figs. S6 and S8 respectively).

The corresponding standard deviation exhibits very low changes over arid areas and permanent great lakes (East African Lakes, Great American Lakes) but large variations over extensive floodplains along large rivers, but also over region with intermediate peakiness in Fig. 10 as the lakes of northern Canada and the floodplain in the Ob' River Basin in Siberia (Fig. 11). Similar behaviors are also observed for the standard deviations of LEW and TES (Figs. S7 and S9 respectively). 

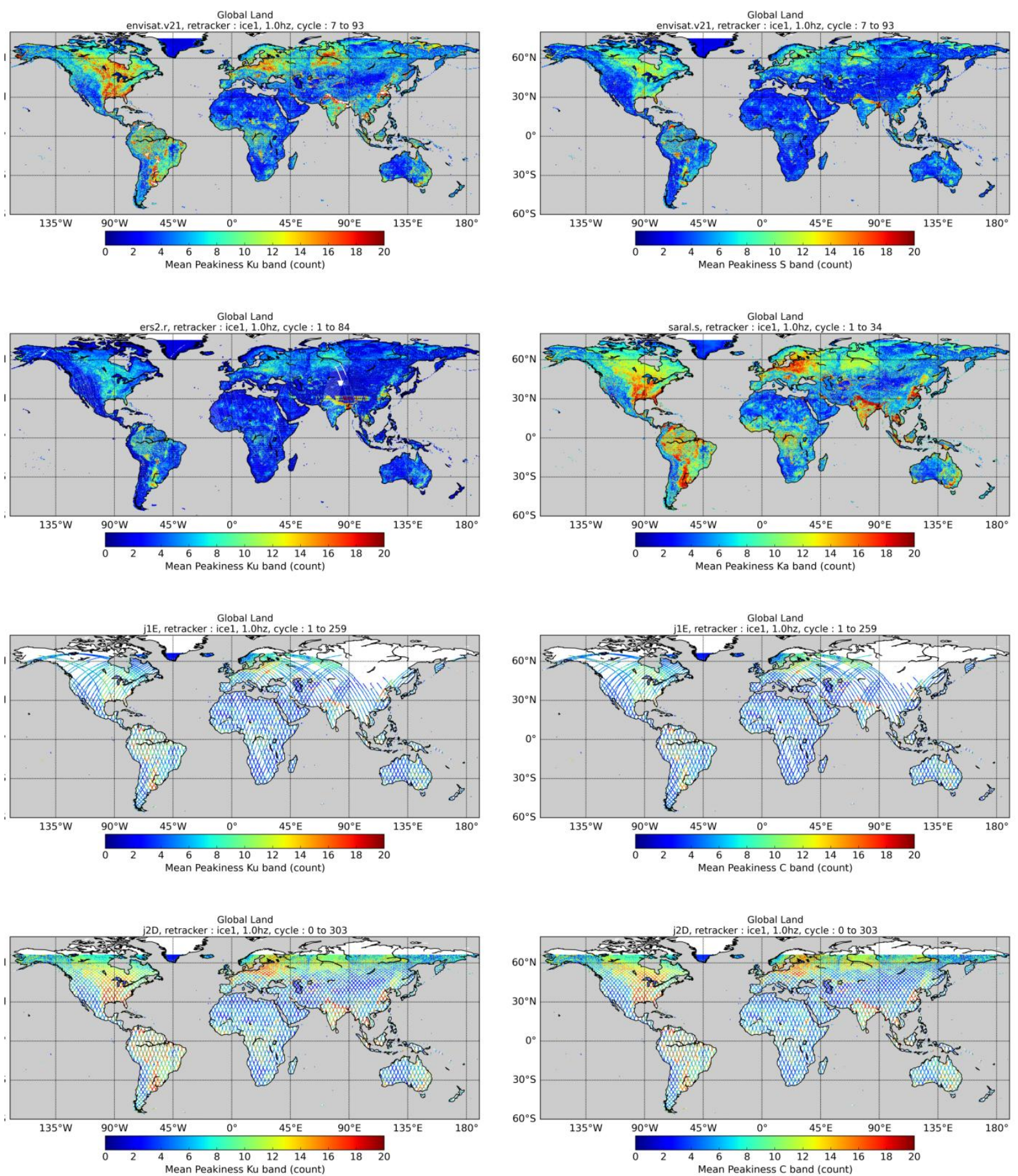

Figure 10: Maps of along-track averaged radar altimetry peakiness (processed using Ice-1 retracker) over land surfaces from ENVISAT at Ku and S band (a, b), ERS-2 at Ku band (c), SARAL at Ka band (d), Jason-1 and 2 at $\mathrm{Ku}$ and $\mathrm{C}$ bands (e, $\mathrm{f})$ and $(\mathrm{g}, \mathrm{h})$ respectively during their nominal orbit period. 

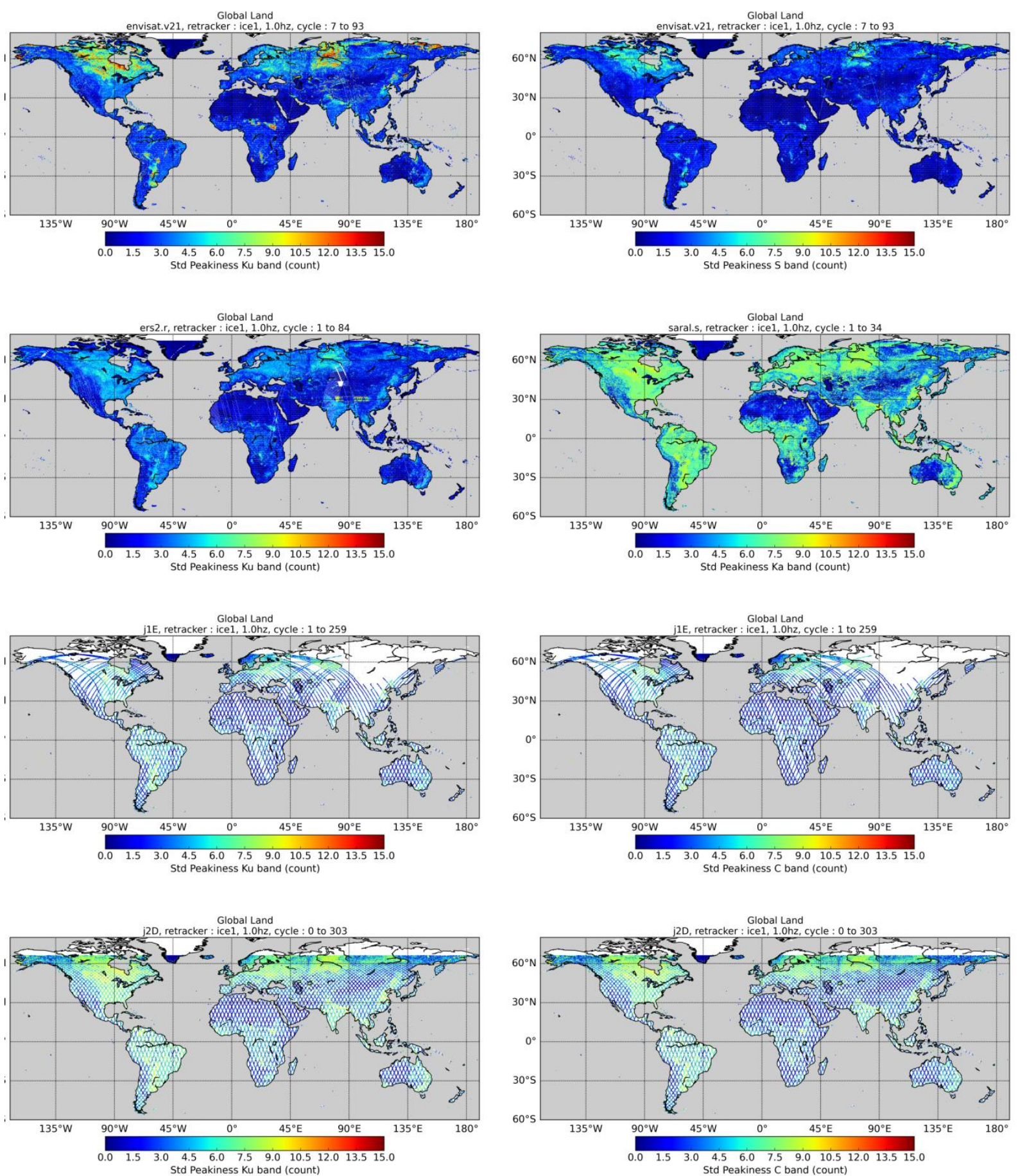

Figure 11: Maps of along-track standard deviation of radar altimetry peakiness (processed using Ice-1 retracker) over land surfaces from ENVISAT at Ku and S band (a, b), ERS-2 at $\mathrm{Ku}$ band (c), SARAL at Ka band (d), Jason-1 and 2 at $\mathrm{Ku}$ and $\mathrm{C}$ bands (e, f) and (g, h) respectively during their nominal orbit period. 


\subsection{Temporal variations of backscattering over selected sites}

Temporal variations of $\sigma_{0}$ are examined in eight different locations at the crossings of radar altimetry tracks from 10-day and 35-day repeat orbit over a wide range of ecological, hydrological and climatic conditions. These time variations are obtained as the median of all the valid $\sigma_{0}$ values in a window of $0.1^{\circ}$ of width centred on the average longitude and latitude given in Table 2. Two sites were selected in the Amazon Basin equatorial forest, two located in the La Plata Basin, one in the Taklamakan, one in the Mekong Basin and two in Siberia. They correspond to a non-flooded equatorial forest (Figs. 12a and b), a flooded forest (Figs. 12c and d), the Parana River (Figs. 12e and f), a flooded savannah (Figs. 12g and h), a desert (Figs. 13a and b), a rice paddy (Figs. 13c and d.), a boreal lake (Figs. 13e and f) and nonflooded forest (Figs. 13g and h).

A quite stable signal is found over the non-flooded equatorial forest (Figs. 12a and b). The following mean values of backscattering coefficient and associated standard deviation are found: $-4.2 \pm 1.2 \mathrm{~dB}$ (Ku-band) for ERS-2, 0.8 $\pm 3.3 \mathrm{~dB}$ (Ku-band) and $-0.9 \pm 2.73 \mathrm{~dB}$ (S-band) for ENVISAT, $1.9 \pm 3.3 \mathrm{~dB}$ (Ka-band) for SARAL, 7.6 $\pm 1.9 \mathrm{~dB}$ (Ku-band) and 10.1 $\pm 2.4 \mathrm{~dB}$

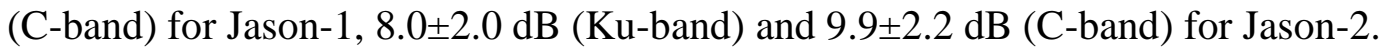

On the contrary, the forest located in the Amazon floodplain (Figs. 12c and d) exhibit large variations between the dry (and the wet (May-June)) periods with a large interannual variability. They can reach up to $30 \mathrm{~dB}$ for Jason-1 and 2, $12 \mathrm{~dB}$ for ERS-2, $20 \mathrm{~dB}$ for ENVISAT and $15 \mathrm{~dB}$ for SARAL. For dual-frequency altimeters, lower minimum values but higher amplitudes are observed at the higher ( $\mathrm{Ku}$ compared with $\mathrm{C}$ and $\mathrm{S})$ frequency. Similar temporal behaviours can be observed at the crossing of the Parana River with a higher backscattering level during high water periods occurring in September/October (Figs 12 e and f) and also over the flooded savannahs present in the La Plata but with a higher amplitude 
between the dry and the wet periods (Figs. $12 \mathrm{~g}$ and $\mathrm{h}$ ). In these two examples, backscattering maxima can reach up to 45 and even $55 \mathrm{~dB}$.

A very stable signal is found over the arid area of the Taklamakan (Figs. 13a and b). The following mean values of backscattering coefficient and associated standard deviation are found: $-5.2 \pm 0.2 \mathrm{~dB}$ (Ku-band) for ERS-2, $-1.6 \pm 1.1 \mathrm{~dB}$ (Ku-band) and 0.4 $\pm 1.5 \mathrm{~dB}$ (S-band) for

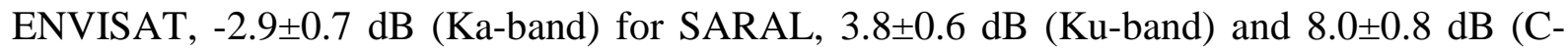

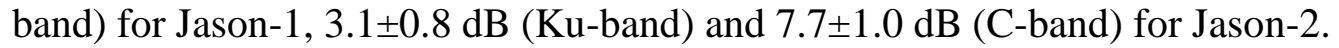

The temporal variations of backscattering over rice paddies in the Mekong delta exhibit a well-marked seasonal cycle of amplitude peaking in September-October, with an annual amplitude around $15 \mathrm{~dB}$ for all the missions except Jason-2 for which the annual amplitude can reach 20 to $25 \mathrm{~dB}$ (Figs. $13 \mathrm{c}$ and d).

The time-series over radar altimetry $\sigma_{0}$ over the Ozero Enetor Siberian Lake exhibit two peaks per year, the first one between April and June when the ice melts and the second one between October and December when the lake surface freezes (Figs. 13e and f). Low values are generally ranging from 5 to $15 \mathrm{~dB}$ for the 35 -day repeat orbit period missions and from 15 to $25 \mathrm{~dB}$ for the 10-day repeat orbit missions. Lower minimum and larger amplitudes are observed as the frequency increases from $\mathrm{S}$ to Ka bands. Similar behaviour can be found over the Siberian forest, related to snow melt in spring and snowfall during fall with lower minimum values (Figs. 13g and h). 

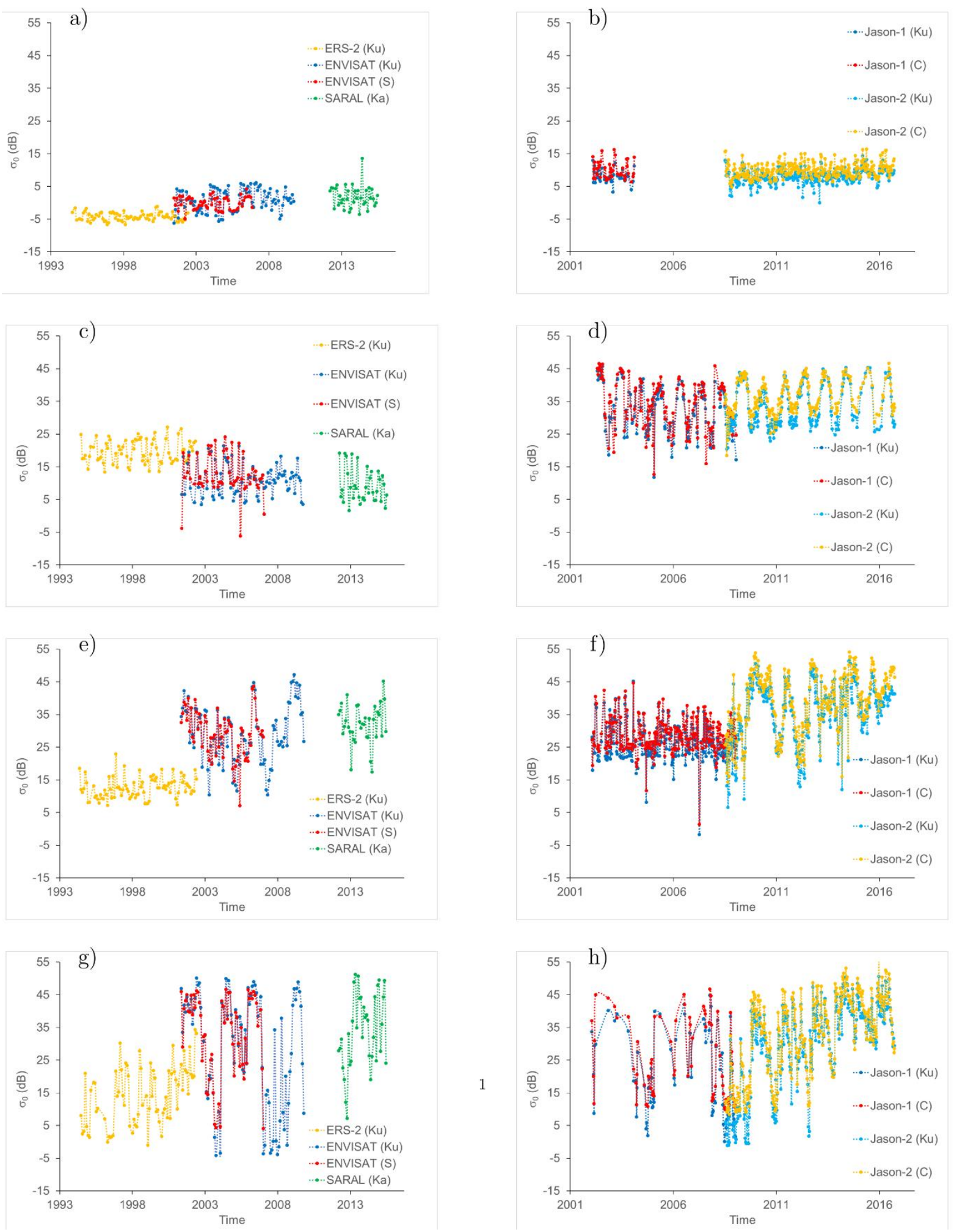

Fig. 12. Time-series of backscattering coefficient derived from the OCOG retracking algorithm

(dB) for 10-day and 35-day repeat period missions over Amazonian non-flooded forest (a and b), Amazonian flooded forest (c and d), Parana River (e and f), flooded savannahs in the 
Parana Basin (g and h).
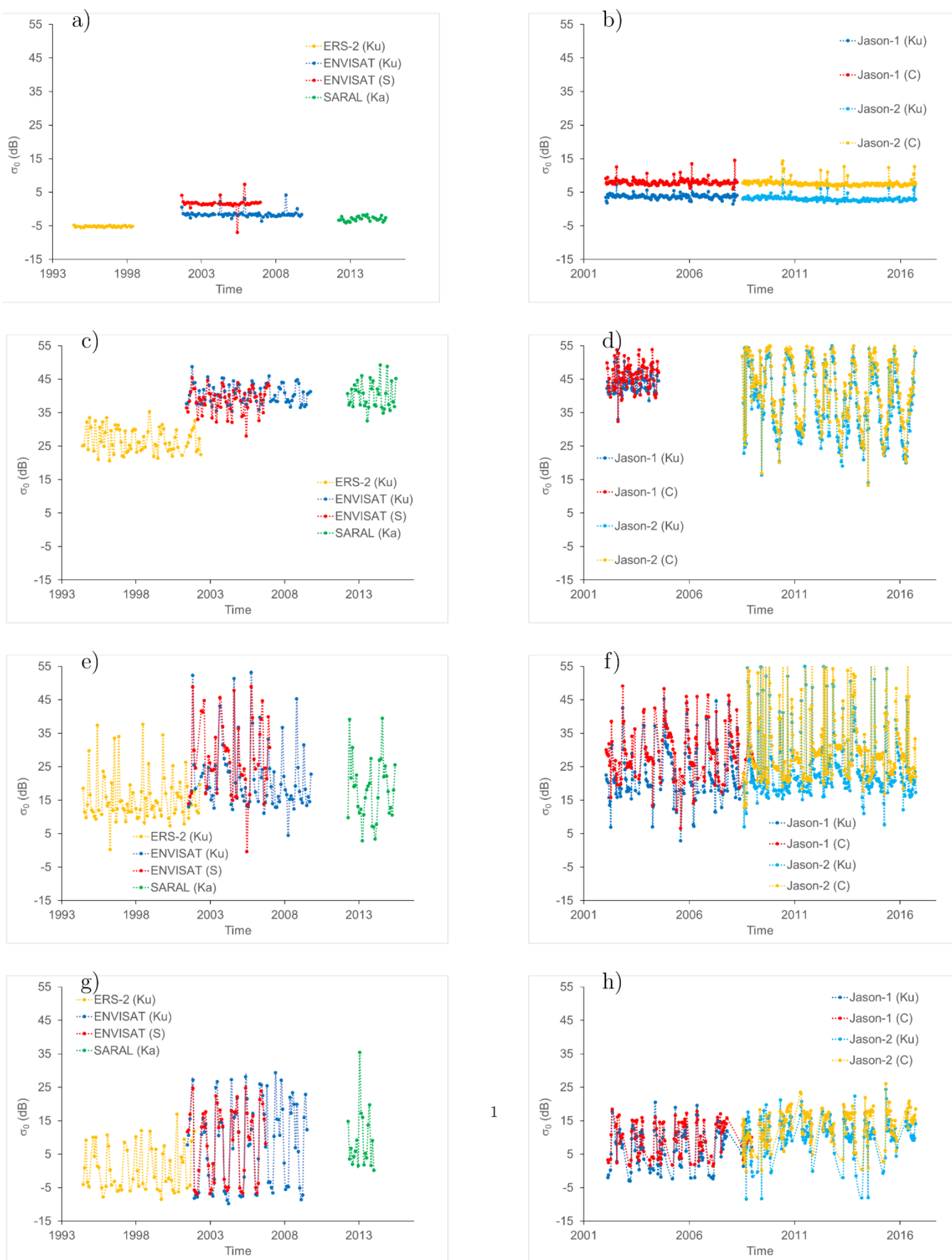

Fig. 13. Time-series of backscattering coefficient derived from the OCOG retracking algorithm

(dB) for 10-day and 35-day repeat period missions over Takla Makan desert (a and b), a rice 
paddy in Vietnam (c and d), Ozero Enetor Siberian Lake (e and f), a Siberian forest ( $g$ and $h$ ).

\section{Discussion}

\subsection{Generalities}

Theoretically, the differences in backscattering between the various frequency bands considered in this study can be accounted for:

i) the antenna aperture of the sensors,

ii) the wavelengths ranging from $0.84 \mathrm{~cm}(35.5 \mathrm{GHz})$ at $\mathrm{Ka}$ band to $9.375 \mathrm{~cm}(3.2 \mathrm{GHz})$ at $\mathrm{S}$ band,

iii) the bandwidth chirp of the radar sensors in the different frequency bands and acquisition modes (Table 1),

iv) the roughness of the surface,

v) the water content of the surface.

The two first parameters are directly related through the following equation (Skolnik, 2002):

$$
\theta_{3 d B}=\frac{1.22 \lambda}{D}
$$

where $\theta_{3 \mathrm{~dB}}$ is the antenna aperture for a $3 \mathrm{~dB}$ attenuation, $\lambda$ is the wavelength of the electromagnetic wave and $\mathrm{D}$ is the diameter of the antenna.

Along with the altimeter range (R), they allow to estimate the size of the radar altimeter footprint. The diameter of the beam-limited illuminated surface, which depends on the $3 \mathrm{~dB}$ two-way antenna beam width (D), is defined as (Femenias et al., 1993):

$$
D=R \tan \left(\theta_{3 d B}\right) \simeq R \theta_{3 d B} \simeq R \frac{1.22 \lambda}{D}
$$

For similar antenna, the altimeter footprint will be lower at $\mathrm{Ka}$ than at $\mathrm{Ku}$ than at $\mathrm{S}$ bands for $\mathrm{R} \sim 800 \mathrm{~km}$, and at $\mathrm{Ku}$ than at $\mathrm{C}$ bands for $\mathrm{R} \sim 1365 \mathrm{~km}$.

The bandwidth chirp (B) governs both the radar range resolution $(\delta \mathrm{R})$ and the tracking gate width ( $\delta \mathrm{t})$ as follows (Chelton et al., 1989; Skolnik, 2002): 


$$
\begin{aligned}
& \delta R=\frac{c}{2 B} \\
& \delta t=\frac{1}{B}
\end{aligned}
$$

where $\mathrm{c}$ is the velocity of light in the vacuum.

As it can be seen in Table 1, all the altimeters operate with a large bandwidth chirp $(\geq 320$ MHz) except ENVISAT at S-band where B=160 MHz. But for ENVISAT at Ku-band and ERS-2, several bandwidth chirps can be used depending on the capability of the altimeter to track changes of height along the tracks. If ENVISAT operated most of the time at $320 \mathrm{MHz}$ of bandwidth chirp over land surfaces except mountainous areas, many ERS-2 acquisitions were achieved at 82.5 MHz (Bogning et al., 2018; Dowson and Berry, 2000). The power received by the altimeter is averaged on a longer time period (see Eq. 20), and smoothed. This is the reason why the average backscattering at Ku-band is lower when estimated using ERS2 acquisitions than ENVISAT ones (Figure 3).

The same surface appears rougher at lower than at higher wavelengths based on the Rayleigh criterion: a surface is considered smooth if (considering the incidence angle equals to zero for a radar altimeter operating in LRM):

$$
h_{r m s}>\frac{\lambda}{8}
$$

where $h_{r m s}$ is the mean height of the surface variations.

The changes of state of the surface, assuming the penetration depth of the electromagnetic wave is small even at $\mathrm{C}$ and $\mathrm{S}$ bands, except over dry sand and snow, modifies the radar altimetry backscattering. Changes in roughness of bare soils from one season to another, of state (e.g., from snow and ice to open water), in vegetation cover and in wetness of the surface (e.g., temporal evolution of the soil moisture, temporary floods) modify both the roughness and the dielectric properties of the surface (Liu et al., 2013; Paillou et al., 2001; Ulaby et al., 1986). 


\subsection{Differences in mean and mean annual amplitude radar altimetry backscattering}

Spatial patterns of backscattering reflect the distribution of the major bio-climatic environment of the Earth (Fig. 3). The behaviours previously observed over West Africa (Fatras et al., 2015; Frappart et al., 2015a) can be generalized. Lower levels of backscattering during the dry season but larger amplitude between the dry and wet seasons are observed at higher frequencies ( $\mathrm{Ku}$ and $\mathrm{Ka}$ bands) rather than at lower frequencies ( $\mathrm{C}$ and $\mathrm{S}$ bands).

The very low backscattering observed over mountainous areas are due to the presence of topography and slopes responsible for a large scattering of the surface and for slight returns of power to the sensor. This is due to the presence of terrain slope in the antenna pattern of the altimeter which impacts the distribution of the scatterers (see Eq. 2 and (Papa et al., 2003)). Low backscattering is also observed over equatorial forests, especially at higher frequencies (Ka and $\mathrm{Ku}$ bands). Three main reasons can account for this behaviour: i) the higher frequencies are interacting more with the canopy (volume backscattering) - the presence of the leaves make the surface rougher at $\mathrm{Ka}$ and $\mathrm{Ku}$ bands than at $\mathrm{C}$ and $\mathrm{S}$ bands based on the Rayleigh criterion, ii) as radar altimeters are nadir-pointing sensors, part of the signal is reflected by the surface under the canopy. For the same reason as in i), more signal is backscattered toward the altimeter at lower frequency. These two types of surface are also characterized by a very low annual amplitude (Figs. 5, 12a and b).

Very stable signal is also found over desert areas (Fig. 3) as previously observed over Australia and Africa (Cudlip et al., 1993; Fatras et al., 2015, 2012; Frappart et al., 2015a; Prigent et al., 2015; Ridley et al., 1996). The backscattering signal is highly dependent of the nature of the soil (sand and rock types) through the dielectric constants and of the surface 
roughness (e.g., size of the sand grains). In Fatras et al., 2015, a small seasonal signal was found over desert of stone in Libya as previously observed in several studies using scatterometer data at C and Ku bands (Frison and Mougin, 1996; Kennett and Li, 1989). This signal was related to a change in the wind regime which periodically modifies the soil roughness in this area (Stephen and Long, 2007, 2005). In the example taken over the Taklamakan desert, the time-series of backscattering also shows a great stability except for a very few dates where changes in amplitude up to $10 \mathrm{~dB}$ can be observed (Figs. 13a and b). These large changes can be attributed to an acquisition achieved shortly after a rainfall (Fatras et al., 2012). Smaller changes lower than $3 \mathrm{~dB}$ can be observed all along the year. Similar variations were observed on scatterometer at C-band and attributed to changes in water phase caused by variations in temperature below and above the freezing point (Paillou et al., 2017). High backscattering values and large annual amplitude of backscattering can be seen over intertropical and northern areas (Figs. 3 and 5). These changes are observed over regions characterized by large annual variations in soil water content, occurrences of extensive flood events and/or presence of ice and snow during winter. Over semi-arid areas as the Sahelian band in Africa, annual amplitude of backscattering can reach up to $15 \mathrm{~dB}$ between the dry (with minima in January-March - Fig. 8) and the wet season (with maxima in August during the peak of the African monsoon - Fig. 7), resulting from an increase of both real and imaginary parts of the dielectric constant (see, for instance, (Fatras et al., 2018; Hallikainen et al., 1985)) and a decrease of the roughness which accounts for stronger power returns to the sensor. In large river basins covered with extensive floodplains, annual amplitude of backscattering larger than $20 \mathrm{~dB}$ can be observed. This large annual amplitude results from a strong increase in the dielectric constant from soil to water and the decrease in roughness between non-flooded and flooded states. They clearly appear in the north Canadian and Siberian watersheds, in the Orinoco and La Plata (see Figs. 12e and f) basins (South 
America), in the Ganges-Brahmaputra and Mekong (see Figs. 13c and d) basins (Asia) but not as clearly in the Congo and the Amazon basins (Fig. 5). However, this is an artefact of visual presentation: when zooming on the floodplains, large annual amplitude clearly appears as it can be seen on the time-series of backscattering over temporarily flooded forests located in the Amazon Basin (Figs. 12c and d) and in the Congo Basin (Frappart et al., 2015a). Over rivers, large amplitude can also be seen resulting of the change in width between low and high water stages (see the examples over the Parana River in Figs. $12 \mathrm{~g}$ and $\mathrm{h}$ and over the Niger River in (Fatras et al., 2018; Frappart et al., 2015a)). At high latitude, large changes in backscattering can be attributed to either the presence of snow adding a volume component of backscattering to the surface component (Papa et al., 2002; Rémy et al., 2015), or the extensive flood events covering large surfaces (Normandin et al., 2018b; Zakharova et al., 2014), or changes of surface state of lakes during freezing and melt events (see Figs. 13e and f). In terms of temporality, the months of occurrence of maxima and minima correspond to the periods of flood and low water stages in the different river basins. A clear separation occurs between the northern and southern hemispheres, very well marked in the Amazon Basin (Figs. 7 and 8). The signature of the monsoon, with maxima of backscattering occurring from August to October, is also clearly visible (Fig. 7). The north-south gradient observed in the northern hemisphere is related to the dates of snow melt which causes large flood events at boreal latitudes (Fig. 7).

\subsection{Differences in mean radar altimetry backscattering and other parameters}

The differences in average backscattering signal ( $\mathrm{S}-\mathrm{Ku}$ for ENVISAT and $\mathrm{C}-\mathrm{Ku}$ for Jason-1 and 2) exhibit complementary patterns from the single backscattering from the same mission. These differences can be used for monitoring changes in vegetation cover, transition between 
bare soil and vegetated areas or wet and dry soils for vegetated areas (see for instance the maps of standard deviations of the differences in Figs. 9 and S5 which show strong gradients between arid and semi-arid as the transitions between Sahara and Sahel or between Central Australia and the Murray-Darling Basin in the east, between mid-latitude and boreal regions in Eurasia) as previously mentioned by (Frappart et al., 2015a; Papa et al., 2003). The novelty in this study is the use over land of other waveform related parameters such as the peakiness from Ice-1 and LEW and TES from Ice-2. Their spatial patterns show very well marked features which can be related to the presence of water over land in particular. Taking into account this information in combination with the backscattering coefficients could be very useful to automatically detect the presence of water over land. Nevertheless, the peakiness is surprisingly more often flagged than the backscattering coefficient derived from Ice-1, the Ice-2 retracking is not performed yet on the Jason missions and is less robust than Ice-1. As it is a physically-based retracking algorithm, model adjustment is not always successful for complex waveforms as the ones observed over land. LEW was found to be lower over inland water bodies (e.g., the altimetry waveform has steep leading edge due to a low roughness and the lack penetration in the medium) than over other land types (Fig. S6).

\section{Conclusion}

This study is the first to provide a comprehensive analysis of the radar altimetry backscattering coefficient at multi-frequencies ( $\mathrm{S}, \mathrm{C}, \mathrm{Ku}$ and $\mathrm{Ka}$ ) and global-scale over land for the following LRM radar altimetry missions: ERS-2, Jason-1, ENVISAT, Jason-2 and SARAL. This analysis was made possible owing to the definition of the normalized pass structure allowing to transform the original GDR products into multi-dimensional arrays 
composed of normalized cell indices, associated to a specific geographical location (longitude, latitude) along each altimeter track in the first dimension, time of data acquisition in the second dimension, the different altimeter variables (range, corrections to the range, altimeter height, backscattering coefficient, peakiness, ...) in the other dimensions. This structure is very useful to make time series and along-track statistical analysis (e.g., (Astudillo et al., 2017)). This structure can be provided by $\mathrm{CTOH}$ for any altimetry mission on a repetitive orbit (ERS-2, Envisat, SARAL, Jason-1, Jason-2, Jason-3, Sentinel-3A and B) upon request.

This study shows a wide range of spatial and temporal variabilities in backscattering over land depending on the nature of the surface. These changes are related to the dielectrical properties and roughness of the surface and their possible evolution against time. Over all type of surfaces, lower backscattering levels are observed during the dry season at higher $(\mathrm{Ku}$ and $\mathrm{Ka})$ than at lower (C and S) frequencies. On the contrary, larger amplitudes are observed at higher $(\mathrm{Ku}$ and $\mathrm{Ka})$ than at lower $(\mathrm{C}$ and $\mathrm{S})$ frequencies between the dry and wet seasons.

Almost constant backscattering is observed over arid areas and equatorial forests, the low temporal variability increasing with the frequency and the sensitivity to roughness. Large changes in amplitude of backscattering (higher than $20 \mathrm{~dB}$ ) are observed over extensive floodplains, even under dense vegetation cover, and semi-arid areas exhibiting high variations of SSM such as Sahel. Other parameters derived from the retracking of the waveforms (e.g., peakiness, slopes of the leading and trailing edges) exhibit a strong potential to identify wetlands whereas difference in backscattering from different bands to discriminate between wet and dry soils and/or bare soil and vegetation areas. Nevertheless, as the outputs from the Ice-2 retracking algorithm are only available for the 35-day repeat orbit missions (ERS-2, ENVISAT and SARAL) and the peakiness from OCOG is more often flagged than the backscattering coefficients, a new retracking of these missions data would be necessary to 
exploit the full potential of these parameters.

The recent launches of Sentinal-3A in February 2016 and Sentinel-3B in April 2018, first radar altimetry missions to operate in SAR mode on a 27-day repeat orbit offer the opportunity to compare the signatures at $\mathrm{Ku}$ and $\mathrm{C}$ bands of almost nadir and nadir looking missions using Jason-3 data which was launched in January 2016. All those new developments will be very important to better characterize land observations from future wide-swath radar altimetry missions such as Surface Water and Ocean Topogaphy (SWOT) to be launched in 2021 .

\section{Acknowledgements}

This study was funded by the French Space Agency (CNES) with the ... grant.

\section{References}

Astudillo, O., Dewitte, B., Mallet, M., Frappart, F., Rutllant, J.A., Ramos, M., Bravo, L., Goubanova, K., Illig, S., 2017. Surface winds off Peru-Chile: Observing closer to the coast from radar altimetry. Remote Sens. Environ. 191. https://doi.org/10.1016/j.rse.2017.01.010

Baghdadi, N., Zribi, M., 2016. Land Surface Remote Sensing in Agriculture and Forest, Land Surface Remote Sensing in Agriculture and Forest. Elsevier.

Benveniste, J., Roca, M., Levrini, G., Vincent, P., Baker, S., Zanife, O., Zelli, C., Bombaci, O., 2001. The radar altimetry mission: RA-2, MWR, DORIS and LRR. ESA Bull. 106, 25101-25108.

Betbeder, J., Gond, V., Frappart, F., Baghdadi, N.N., Briant, G., Bartholome, E., 2014. Mapping of central africa forested wetlands using remote sensing. IEEE J. Sel. Top. Appl. Earth Obs. Remote Sens. 7. https://doi.org/10.1109/JSTARS.2013.2269733

Blarel, F., Frappart, F., Legrésy, B., Blumstein, D., Rémy, F., Fatras, C., Mougin, E., Papa, F., Prigent, C., Niño, F., Borderies, P., Biancamaria, S., Calmant, S., 2015. Altimetry backscattering signatures at $\mathrm{Ku}$ and $\mathrm{S}$ bands over land and ice sheets, in: Proceedings of SPIE - The International Society for Optical Engineering. https://doi.org/10.1117/12.2194498

Bogning, S., Frappart, F., Blarel, F., Niño, F., Mahé, G., Bricquet, J.P., Seyler, F., Onguéné, R., Etamé, J., Paiz, M.C., Braun, J.J., 2018. Monitoring water levels and discharges using radar altimetry in an ungauged river basin: The case of the Ogooué. Remote Sens. 10, 350. https://doi.org/10.3390/rs10020350

Bonnefond, P., Verron, J., Aublanc, J., Babu, K.N., Bergé-Nguyen, M., Cancet, M., Chaudhary, A., Crétaux, J.-F., Frappart, F., Haines, B., Laurain, O., Ollivier, A., Poisson, 
J.-C., Prandi, P., Sharma, R., Thibaut, P., Watson, C., 2018. The Benefits of the Ka-Band as Evidenced from the SARAL/AltiKa Altimetric Mission: Quality Assessment and Unique Characteristics of AltiKa Data. Remote Sens. 10, 83. https://doi.org/10.3390/rs10010083

Bourrel, L., Phillips, L., Moreau, S., 2009. The dynamics of floods in the Bolivian Amazon Basin. Hydrol. Process. 23, 3161-3167. https://doi.org/10.1002/hyp.7384

Brown, G., 1977. The average impulse response of a rough surface and its applications. IEEE Trans. Antennas Propag. 25, 67-74. https://doi.org/10.1109/TAP.1977.1141536

Carayon, G., Steunou, N., Courrière, J.L., Thibaut, P., 2003. Poseidon-2 radar altimeter design and results of in-flight performances. Mar. Geod. 26, 159-165. https://doi.org/10.1080/714044516

Chelton, D.B., Walsh, E.J., MacArthur, J.L., 1989. Pulse Compression and Sea Level Tracking in Satellite Altimetry. J. Atmos. Ocean. Technol. 6, 407-438. https://doi.org/10.1175/1520-0426(1989)006<0407:pcaslt>2.0.co;2

Crétaux, J.-F., Nielsen, K., Frappart, F., Papa, F., Calmant, S., Benveniste, J., 2017. Hydrological applications of satellite altimetry: rivers, lakes, man-made reservoirs, inundated areas., in: Stammer, D., Cazenave, A. (Eds.), Satellite Altimetry Over Oceans and Land Surfaces, Earth Observation of Global Changes. CRC Press, pp. 459-504.

Cudlip, W., Ridley, J., Strawbridge, F., Harris, A., Rapley, C., 1993. Detecting Surface Roughness and Moisture Variations in Deserts, Proceedings of the 2nd ERS-1 Symposium, Hamburg 1993, ESA SP-361.

Desjonquères, J.D., Carayon, G., Steunou, N., Lambin, J., 2010. Poseidon-3 Radar Altimeter: New Modes and In-Flight Performances. Mar. Geod. 33, 53-79. https://doi.org/10.1080/01490419.2010.488970

Dowson, M., Berry, P.A.M., 2000. Envisat RA-2: potential for land topo-graphic mapping, in: European Space Agency, (Special Publication) ESA SP(461). pp. 957-965.

ESA, 2007. ENVISAT RA2/MWR Product Handbook.

Fatras, C., Borderies, P., Frappart, F., Mougin, E., Blumstein, D., Niño, F., 2018. Impact of surface soil moisture variations on radar altimetry echoes at $\mathrm{Ku}$ and $\mathrm{Ka}$ bands in semiarid areas. Remote Sens. 10. https://doi.org/10.3390/rs10040582

Fatras, C., Frappart, F., Mougin, E., Frison, P.-L., Faye, G., Borderies, P., Jarlan, L., 2015. Spaceborne altimetry and scatterometry backscattering signatures at $\mathrm{C}$ - and $\mathrm{Ku}$-bands over West Africa. Remote Sens. Environ. 159. https://doi.org/10.1016/j.rse.2014.12.005

Fatras, C., Frappart, F., Mougin, E., Grippa, M., Hiernaux, P., 2012. Estimating surface soil moisture over Sahel using ENVISAT radar altimetry. Remote Sens. Environ. 123. https://doi.org/10.1016/j.rse.2012.04.013

Femenias, P., Remy, F., Raizonville, R., Minster, J.F., 1993. Analysis of satellite-altimeter height measurements above continental ice sheets. J. Glaciol. 39, 591-600. https://doi.org/10.1017/S0022143000016488

Frappart, F., Fatras, C., Mougin, E., Marieu, V., Diepkilé, A.T., Blarel, F., Borderies, P., 2015a. Radar altimetry backscattering signatures at $\mathrm{Ka}, \mathrm{Ku}, \mathrm{C}$, and $\mathrm{S}$ bands over West Africa. Phys. Chem. Earth 83-84, 96-110. https://doi.org/10.1016/j.pce.2015.05.001

Frappart, F., Legrésy, B., Niño, F., Blarel, F., Fuller, N., Fleury, S., Birol, F., Calmant, S., 2016. An ERS-2 altimetry reprocessing compatible with ENVISAT for long-term land and ice sheets studies. Remote Sens. Environ. 184. https://doi.org/10.1016/j.rse.2016.07.037

Frappart, F., Papa, F., Marieu, V., Malbeteau, Y., Jordy, F., Calmant, S., Durand, F., Bala, S., 2015b. Preliminary Assessment of SARAL/AltiKa Observations over the GangesBrahmaputra and Irrawaddy Rivers. Mar. Geod. 38. https://doi.org/10.1080/01490419.2014.990591 
Frison, P.-L.L., Jarlan, L., Mougin, E., 2016. Using satellite scatterometers to monitor continental surfaces, in: Land Surface Remote Sensing in Continental Hydrology. Elsevier, pp. 79-113. https://doi.org/10.1016/B978-1-78548-104-8.50003-6

Frison, P.L., Mougin, E., 1996. Monitoring global vegetation dynamics with ERS-1 wind scatterometer data. Int. J. Remote Sens. 17, 3201-3218. https://doi.org/10.1080/01431169608949139

Gstaiger, V., Huth, J., Gebhardt, S., Wehrmann, T., Kuenzer, C., 2012. Multi-sensoral and automated derivation of inundated areas using TerraSAR-X and ENVISAT ASAR data. Int. J. Remote Sens. 33, 7291-7304. https://doi.org/10.1080/01431161.2012.700421

Guo, J., Yang, L., Liu, X., Chang, X., Hwang, C., 2013. Decadal Variation in Surface Characteristics over Xinjiang, Western China, from T/P Altimetry Backscatter Coefficients: Evidence of Climate Change. Terr. Atmos. Ocean. Sci. 24.

Hallikainen, M., Ulaby, F., Dobson, M., El-rayes, M., Wu, L., 1985. Microwave Dielectric Behavior of Wet Soil-Part 1: Empirical Models and Experimental Observations. IEEE Trans. Geosci. Remote Sens. GE-23, 25-34. https://doi.org/10.1109/TGRS.1985.289497

Kennett, R.G., Li, F.K., 1989. Seasat over-land scatterometer data - I: Global overview of the Ku-band backscatter coefficients. IEEE Trans. Geosci. Remote Sens. 27, 592-605. https://doi.org/10.1109/TGRS.1989.35942

Kouraev, A. V., Papa, F., Buharizin, P.I., Cazenave, A., Cretaux, J.F., Dozortseva, J., Remy, F., 2003. Study and monitoring of sea ice cover in the caspian and aral seas from TOPEX/POSEIDON microwave data. Elsevier Oceanogr. Ser. 69, 141-145. https://doi.org/10.1016/S0422-9894(03)80024-7

Kouraev, A. V., Semovski, S. V., Shimaraev, M.N., Mognard, N.M., Légresy, B., Remy, F., 2007. Observations of Lake Baikal ice from satellite altimetry and radiometry. Remote Sens. Environ. 108, 240-253. https://doi.org/10.1016/j.rse.2006.11.010

Kouraev, A. V., Shimaraev, M.N., Buharizin, P.I., Naumenko, M.A., Crétaux, J.F., Mognard, N., Legrésy, B., Rémy, F., 2008. Ice and snow cover of continental water bodies from simultaneous radar altimetry and radiometry observations. Surv. Geophys. 29, 271-295. https://doi.org/10.1007/s10712-008-9042-2

Kuenzer, C., Guo, H., Huth, J., Leinenkugel, P., Li, X., Dech, S., 2013. Flood mapping and flood dynamics of the mekong delta: ENVISAT-ASAR-WSM based time series analyses. Remote Sens. 5, 687-715. https://doi.org/10.3390/rs5020687

Laxon, S.W., Rapley, C.G., 1987. Radar altimeter data quality flagging. Adv. Sp. Res. 7, 315318. https://doi.org/10.1016/0273-1177(87)90332-2

Legrésy, B., Papa, F., Remy, F., Vinay, G., van den Bosch, M., Zanife, O.-Z., 2005. ENVISAT radar altimeter measurements over continental surfaces and ice caps using the ICE-2 retracking algorithm. Remote Sens. Environ. 95, 150-163. https://doi.org/10.1016/J.RSE.2004.11.018

Legrésy, B., Rémy, F., 1997. Altimetric observations of surface characteristics of the Antarctic ice sheet. J. Glaciol. 43, 265-275. https://doi.org/10.1017/S002214300000321X

Levrini, G., Rubertone, F.S., Ruehe, W., 1984. The ERS-1 radar altimeter instrument. ESA ERS-1 Radar Altim. Data Prod. p 17-22 (SEE N85-12419 03-43).

Liu, C., Zhang, L., Peng, J., Srinivasakannan, C., Liu, B., Xia, H., Zhou, J., Xu, L., 2013. Temperature and Moisture Dependence of the Dielectric Properties of Silica Sand. J. Microw. Power Electromagn. Energy 47, 199-209. https://doi.org/10.1080/08327823.2013.11689858

Normandin, C., Frappart, F., Diepkilé, A.T., Marieu, V., Mougin, E., Blarel, F., Lubac, B., Braquet, N., Ba, A., 2018a. Evolution of the performances of radar altimetry missions from ERS-2 to Sentinel-3A over the Inner Niger Delta. Remote Sens. 10, 833. 
https://doi.org/10.3390/rs10060833

Normandin, C., Frappart, F., Lubac, B., Bélanger, S., Marieu, V., Blarel, F., Robinet, A., Guiastrennec-Faugas, L., 2018b. Quantification of surface water volume changes in the Mackenzie Delta using satellite multi-mission data. Hydrol. Earth Syst. Sci. 22, 15431561. https://doi.org/10.5194/hess-22-1543-2018

Oberstadler, R., Hönsch, H., Huth, D., 1996. Assessment of the mapping capabilities of ERS1 SAR data for flood mapping: A case study in Germany. Eur. Sp. Agency, (Special Publ. $\quad$ ESA SP 11, 247-252. https://doi.org/10.1002/(SICI)10991085(199708)11:10<1415::AID-HYP532>3.0.CO;2-2

Paillou, P., Grandjean, G., Malézieux, J.M., Ruffié, G., Heggy, E., Piponnier, D., Dubois, P., Achache, J., 2001. Performances of ground penetrating radars in arid volcanic regions: Consequences for Mars subsurface exploration. Geophys. Res. Lett. 28, 911-914. https://doi.org/10.1029/1999GL008449

Paillou, P., Gruhier, C., Sufyar, S., Lopez, S., 2017. (PDF) Use of QuikSCAT Scatterometer for the Monitoring of Seasonal Changes of Soil Properties in the Badain Jaran, China [WWW Document].

URL https://www.researchgate.net/publication/321333254_Use_of_QuikSCAT_Scatterometer _for_the_Monitoring_of_Seasonal_Changes_of_Soil_Properties_in_the_Badain_Jaran_ China (accessed 12.30.19).

Papa, F., Legresy, B., Mognard, N.M., Josberger, E.G., Remy, F., 2002. Estimating terrestrial snow depth with the Topex-Poseidon altimeter and radiometer. IEEE Trans. Geosci. Remote Sens. 40, 2162-2169. https://doi.org/10.1109/TGRS.2002.802463

Papa, F., Legrésy, B., Rémy, F., 2003. Use of the Topex-Poseidon dual-frequency radar altimeter over land surfaces. Remote Sens. Environ. 87, 136-147. https://doi.org/10.1016/S0034-4257(03)00136-6

Papa, F., Prigent, C., Rossow, W.B., Legresy, B., Remy, F., 2006. Inundated wetland dynamics over boreal regions from remote sensing: the use of Topex-Poseidon dual- frequency radar altimeter observations. Int. J. Remote Sens. 27, 4847-4866. https://doi.org/10.1080/01431160600675887

Peacock, N.R., Laxon, S.W., 2004. Sea surface height determination in the Arctic Ocean from ERS altimetry. J. Geophys. Res. C Ocean. 109, C07001. https://doi.org/10.1029/2001JC001026

Prigent, C., Aires, F., Jimenez, C., Papa, F., Roger, J., 2015. Multiangle Backscattering Observations of Continental Surfaces in Ku-Band (13 GHz) From Satellites: Understanding the Signals, Particularly in Arid Regions. IEEE Trans. Geosci. Remote Sens. 53, 1364-1373. https://doi.org/10.1109/TGRS.2014.2338913

Remy, F., 2016. Radar altimetry for monitoring the antarctic ice sheet, in: Land Surface Remote Sensing in Continental Hydrology. Elsevier, pp. 231-254. https://doi.org/10.1016/B978-1-78548-104-8.50007-3

Rémy, F., Flament, T., Michel, A., Blumstein, D., 2015. Envisat and SARAL/AltiKa Observations of the Antarctic Ice Sheet: A Comparison Between the Ku-band and Kaband. Mar. Geod. 38, 510-521. https://doi.org/10.1080/01490419.2014.985347

Ridley, J., Strawbridge, F., Card, R., Phillips, H., 1996. Radar backscatter characteristics of a desert surface. Remote Sens. Environ. 57, 63-78. https://doi.org/10.1016/00344257(96)00018-1

Salameh, E., Frappart, F., Marieu, V., Spodar, A., Parisot, J.P., Hanquiez, V., Turki, I., Laignel, B., 2018. Monitoring sea level and topography of coastal lagoons using satellite radar altimetry: The example of the Arcachon Bay in the Bay of Biscay. Remote Sens. 10, 297. https://doi.org/10.3390/rs10020297

Skolnik, M.I., 2002. Radar, in: Reference Data for Engineers. Elsevier, pp. 36-1-36-22. 
https://doi.org/10.1016/B978-075067291-7/50038-8

Stephen, H., Long, D.G., 2007. Spatial and temporal behavior of microwave backscatter directional modulation over the saharan ergs. IEEE Trans. Geosci. Remote Sens. 45, 1164-1173. https://doi.org/10.1109/TGRS.2007.892584

Stephen, H., Long, D.G., 2005. Microwave backscatter modeling of erg surfaces in the Sahara desert. IEEE Trans. Geosci. Remote Sens. 43, 238-246. https://doi.org/10.1109/TGRS.2004.840646

Steunou, N., Desjonquères, J.D., Picot, N., Sengenes, P., Noubel, J., Poisson, J.C., 2015. AltiKa Altimeter: Instrument Description and In Flight Performance. Mar. Geod. 38, 22 42. https://doi.org/10.1080/01490419.2014.988835

Uebbing, B., Forootan, E., Braakmann-Folgmann, A., Kusche, J., 2017. Inverting surface soil moisture information from satellite altimetry over arid and semi-arid regions. Remote Sens. Environ. https://doi.org/10.1016/j.rse.2017.05.004

Ulaby, F.T., Moore, R.K., Fung, A.K., 1986. Microwave remote sensing: active and passive. Volume III: from theory to applications. Microw. Remote Sens. Act. Passiv. Vol. III from theory to Appl.

Wingham, D.J., Rapley, C.G., Griffiths, H., 1986. New Techniques in Satellite Altimeter Tracking Systems. Proc. IGARSS Symp. Zurich 1339-1344.

Zakharova, E.A., Kouraev, A. V., Rémy, F., Zemtsov, V.A., Kirpotin, S.N., 2014. Seasonal variability of the Western Siberia wetlands from satellite radar altimetry. J. Hydrol. 512, 366-378. https://doi.org/10.1016/j.jhydrol.2014.03.002 